\title{
Information and Communication Technologies and Human Resources in Hospitality and Tourism \\ ABSTRACT
}

Purpose: ICTs play a key role in the tourism sector, influencing the labor context amongst other things. Hence the objective of this work: a review of the literature in which the topics of Tourism, ICTs, and Human Resources converge through an analysis of the articles published in the relevant journals, which are included in the Web of Science.

Design/Methodology/Approach: The 60 articles analyzed - published over a period of 31 years- - were studied according to several criteria such as: research methodology, statistical techniques utilized, topics dealt with, technologies addressed, authors, and countries.

Findings: The topics under study were divided into 4 broad areas - Technology \& Employees, Technology \& HR Processes, Technology \& Results, and Technology \& Organizational Structure - the first, which focuses on how employees behave in relation to technology, received the most attention.

Limitations/Implications: The literature review was confined to articles on the topics of Tourism, ICTs, and Human Resources published in 73 academic journals, leaving aside other research sources, e.g. books and papers presented at conferences. This work can be useful both in the academic field and for tourism firm managers - especially those in ICT and Human Resources.

Originality/Value: Although there are several previous reviews of the literature on Human Resource Management and ICTs in the Tourism sector, none of them has jointly examined these three topics.

Keywords: Systematic Literature Review, Information and Communication Technologies, Human Resources, Hospitality and Tourism Research

\section{Introduction}

Information and Communication Technologies (ICTs) have affected the manner in which tourism organizations perform their business activities; especially influencing how they address their markets (Abellá Garcés et al., 2004). This fact, along with the demands of increasingly sophisticated customers and the need for faster communication with all kinds of partners make ICTs essential to the tourism sector. ICTs allow the industry to achieve its current objectives and design its own future (Law et al., 2013). Also, the way in which employees work and communicate nowadays is very different to how it was in the past (Kim and Gatling, 2018). ICTs have changed the world of labor. Workers connect with other employees or with their line managers by means of technologies; they learn using technological platforms and job searches, recruitment and in-firm socializing are conducted through ICTs.

For the reasons stated above, research on the use of ICTs in the tourism sector (Law et al., 2013) as well as on their adoption in practices related to Human Resources has increased (Ali et al., 2019; Janta and Ladkin, 2013). An extensive volume of literature has also been dedicated to Human Resource practices in the tourism sector (Davidson et al., 2011). Our work seeks to analyze the area into which all three topics - Tourism, ICTs, and Human Resources - converge. It is our intention to examine the academic literature that jointly covers the three topics through the following questions:

- Which journals deal with these issues?

- Which research methodologies are the most often used?

- Which statistical techniques do they apply?

- Which topics arise in this area of confluence between tourism, ICTs, and human resources? 
- Which technologies are analyzed?

- Which authors and countries are most prolific in this field?

Previous studies have proposed similar questions about ICTs and Tourism (Shen et al., 2018; González et al., 2019; González et al., 2013) with a related objective: improving our knowledge about a specific field of study. A systematic review of research in this area helps us analyze the literature on ICTs and Human Resources in Tourism. As opposed to a traditional narrative literature review - usually criticized for its subjectivity and lack of relevance and scientific rigor (Hart, 1998) - a systematic literature review is a rigorous, replicable, scientific and transparent process (Tranfield et al., 2003; Marasco et al., 2018). This type of review can not only help us acquire a better knowledge of what has been studied at this crossroads between Tourism, ICTs and Human Resources but will also help us identify potential paths for the future; showing tourism sector managers which technologies should be explored and for what purpose.

\section{Data Collection}

Our interest focuses on examining articles published in renowned journals dedicated to Tourism, Human Resources and Information Systems. We will not, therefore, analyze works exclusively published for conferences, since relevant studies presented at such events later appear in prestigious journals or books, as they are usually aimed at disseminating established knowledge. Hence why previous bibliographic studies revolving around tourism have exclusively focused on examining articles (Okumus et al., 2018; Law et al., 2013; Leung et al., 2013; Shen et al., 2018, Nusair et al., 2019).

Our study articles are found on the Web of Science (WoS), which is one of the most prestigious databases used in academic research. Zupic and Carter (2015) revealed that $69.1 \%$ of bibliometric studies in the field of Management and Organization had used WoS. Previous works used this database as the only source to perform a systematic review of literature in the Hospitality and Tourism area (Gomezelj, 2016). Every journal included in this systematic literature review is also indexed in the Scopus and ProQuest databases.

Attention is firstly paid to journals indexed in the WoS's JCR 2018 within the area of Hospitality, Leisure, Sports and Tourism (52 journals) - from which those solely belonging to the sports domain (25) are removed, thus leaving us with 27 journals to analyze. The articles found contain the following terms in their abstracts and/or keywords: CRS, e-Tourism, eWOM, GDS, GIS, GPS, Information Systems, Information Technology, Intelligent Agents, Intelligent Interface, Internet, Social networks, Website or Technology, and Employee, Human Resources or Personnel. We thus end up with 53 tourism-related articles as shown in Table 1.

Out of 217 journals indexed in JCR 2018 of the WoS under the management heading, 31 focus on Human Resources. From these 31 journals we searched for articles which include in their abstracts and/or keywords terms such as Hospitality, Hotel, Restaurant, Travel or Tourism and whose content deals with ICTs. Through this strategy we found 5 articles.

Finally, we searched for articles from journals devoted to Information Systems, an area in which WoS's JCR has no specific heading - hence our decision to use rankings developed by different authors to identify the best journals in the Information Systems area. Thus, after analyzing the lists of Lowry et al. (2013), Everard et al. (2017), Iyengar and Balijepally (2015), Chan et al. (2015), and Jiang et al. (2017) we examined 15 journals (which additionally fulfilled the requirement of appearing in JCR 2018 of the 
WoS). ${ }^{1}$ We then looked for articles which also contained in their abstract and/or keywords terms like Hospitality, Hotel, Restaurant, Travel or Tourism, amongst others, and whose content revolved around Human Resources. Only two articles were found (Table 1).

The list of search terms applied to Tourism, Human Resources, and Information Systems journals was established by means of a brainstorming exercise amongst the authors of this work, after reviewing the previous literature. This search method has already been utilized by other scholars (Hung and Law, 2011; González et al., 2019).

A total of 60 articles were analyzed, as shown in Table 5 of the APPENDIX, where they appear together with their methodologies, research topics, and key findings. The search for the articles finished in February 2020, and articles published until 2019 were included.

\section{INSERT TABLE 1}

\section{Results}

\subsection{Research Areas and Time Frame}

Even though our field of study encompasses Tourism, Human Resources, and ICTs, most of the articles dealing with these themes on a joint basis are found in tourism journals; $88.3 \%$ of the works analyzed. Information Systems journals hardly ever deal with this topic. IJCHM and IJHM are equally prolific journals in this domain (with 14 published articles each) and, within the area of Information Systems, only the journal I\&M addressed the field of Human Resources and Tourism -with 2 articles. As for Human Resources, NTW\&E - with 3 articles - alongside PR and TIJHRM - with 1 article each - were the only ones which published articles on these themes.

In an attempt to examine the evolution over time of the literature under study, the time frame for article publication was divided into three stages: until 1999; from 2000 to 2009; and from 2010 to 2019, inclusive. The number of published articles within this area has grown notably during each period.

\subsection{Research Methods, Statistical Techniques, and Countries}

\subsubsection{Research Methods}

The research methodology essentially reveals how the data underpinning this research were obtained. Previous systematic reviews - e.g. the seminal work written by Van Horn (1973) and those authored by González et al. (2013) and González et al. (2019) - helped us classify articles according to their research methodology (Table 2).

INSERT TABLE 2

Amongst empirical works we can highlight those based on field studies and on surveys. The former study people in their natural environment (in the workplace when it comes to HRs) to gather data. The data provided by surveys are not necessarily collected where they originate. However, a quantitative approach to information collection prevails in both cases, since they largely depend on the joint analysis of large data volumes aimed at drawing overall conclusions which can subsequently be extrapolated to the whole set of cases. These are the methods adopted by 26 of our articles and the ones which have grown to a larger extent over time.

Another 11 articles are based on case studies and/or use interviews as their main information-gathering tool. Case studies essentially refer to one or several organizations

${ }^{1}$ Readers can request the list of the 27 Tourism journals, the 31 journals dedicated to Human Resources, and the 15 journals focused on Information Systems which were reviewed to collect our articles. 
analyzed by means of several methods: direct observation, document analyses, and interviews, to quote but a few. Therefore, some case studies rely on interviews. Unlike field studies, case studies and interviews are qualitative methods where information comes from one or few organizations, or from a limited number of interviewees, which makes it more difficult to generalize their conclusions. Nonetheless, the information obtained is outstandingly richer than that collected by means of surveys. For this reason, they are suitable for areas with little previous research and evidence where new signs are needed in order to move ahead.

A total of 4 articles use experiments — all of them recent — published from 2010 onwards. These experiments place specific organizations or individuals in simulated situations which try to emulate reality to see how they would respond when faced with such situations. As with our paper the 4 articles adopted the format of a literature review, using previous research works as their source of information; hence why a meta-analysis was performed with the aim of compiling and synthesizing the research on a certain area.

Three articles followed the research methodology known as content analysis, where the information used does not come from primary information - directly obtained by the researcher - but from secondary means of information, e.g. databases, web pages (e.g. Internet forums in the study authored by Janta and Ladkin (2013), or social media, such as Glassdoor, in the work of Stamolampros et al., (2019)). Finally, three recent articles combine two methods: content analysis and interviews.

Theoretical works rely on ideas and conceptual structures rather than on a direct, systematic observation of reality. Only 9 of the articles found can be classified as essentially theoretical. Many of them basically emphasize the virtues of ICTs. Other theoretical works deal with future trends, such as those authored by Woods (1999) or Sigala (2018). Table 2 reveals the prevalence of empirical over theoretical works and that the number of empirical articles has kept increasing over time.

\subsubsection{Statistical Techniques}

Along the lines of previous bibliometric studies (Leung et al., 2015; González, et al., 2019), an analysis of the statistical techniques utilized in the articles examined is offered below. While words prevail over numbers in theoretical articles, empirical studies use numerical data that must be analyzed with various statistical techniques. Although an article may use one or several techniques, a decision was made to classify works according to the most complex technique applied. The degree of complexity ranges from merely descriptive statistical analyses to univariate analyses (e.g. Means Differences, ANOVA, ANCOVA or Chi-square tests, and Crosstabulations), Multivariate analyses (including Regression, Discriminant Analysis, Factor Analysis, Cluster Analysis or Multidimensional Scaling), SEM analyses (Structural Equation Models), and finally PATH (or pattern) analyses which, despite being multivariate models, are included because of their growing popularity.

Table 2 shows that many articles use no statistical techniques - these are mainly theoretical studies or case studies based on interviews lacking any numerical data. Nonetheless, one can easily see the increasing relevance acquired by SEM/PATH models as well as by multivariate techniques (not used in the first period analyzed), and also that merely descriptive or univariate techniques are seldom used, which reaveals the sophistication achieved by research in this field.

\subsubsection{Countries}

Our third focus of attention is the countries on which the articles are based. Figure 1 shows that the US is the subject of the largest number of articles on the use of ICTs in 
the field of Human Resources and Tourism, followed at a certain distance by China and South Korea. Malaysia, Spain, and the United Kingdom had two articles each. Another 9 articles focused elsewhere i.e., Austria, Australia, Greece, Norway, the Netherlands, South Africa, Switzerland, Taiwan, and Latin America. Finally, 22 articles either had a theoretical nature or consisted in a literature review, or were based on secondary information sources such as databases or contents of web pages or social networks, and consequently did not specify which country or location they focus on.

\section{INSERT FIGURE 1}

\subsection{Topics and Technologies}

\subsubsection{Topics}

While classifying topics, we neither tried to limit categories nor let ourselves be guided by preconceived ideas. This is an open classification, i.e. more articles have appeared as we analyzed new topics (Smith and Kumar, 2004). Some articles essentially refer to one topic, whereas others address several; hence why the sum of all the topics examined amounts to 80 -instead of 60 - as shown in Table 3. Even though each article may deal with various themes, as can be inferred from its keywords, priority was given to those related to the domain of ICTs and Human Resources in the tourism sector leaving aside other aspects which are alien to this confluence of themes. 18 topics were identified like this (see Table 3 and Figure 2).

\section{INSERT TABLE 3}

INSERT FIGURE 2

The 18 topics were classified into four broad areas: a) Technology \& Employees; b) Technology \& HR Processes; c) Technology \& Results; and d) Technology \& Organizational Structures. Table 5 (APPENDIX) shows the different topics and areas and includes useful information on each paper's key findings. The contents of Table 5 are presented in reverse chronological order, so that the reader can see the evolution of key findings over time. It should be added that these key findings are only those that are relevant to this study - ICTs and Human Resources in Tourism. Consequently, the papers analyzed may contain other important findings not dealt with here.

\section{a) Technology \& Employees}

TAM. 9 works deal with the TAM model and its derivatives. TAM (Technology Acceptance Model) examines the behavior of users when faced with these types of innovations, including the usefulness of technology and its user-friendliness. Likewise, TRAM (Technology Readiness and Acceptance Model) - derived from the TAM model - combines technology readiness with its acceptance. The TTF (Task Technology Fit) model also relies on an extension of TAM where the interest refers to how technologies match the tasks where those technologies are used. These three closely interrelated models have proved helpful to understand the extent to which tourism sector employees use different technologies (Huh et al., 2009; Kaushik and Rahman, 2017; Kim et al., 2008).

Satisfaction. Customer satisfaction is undoubtedly one of the most significant issues from a marketing point of view, but this article revolves around employee satisfaction. There are 4 works that emphasize jointly assessing the degree of satisfaction obtained by tourism employees when using ICTs. Amongst them stand out the study undertaken by $\mathrm{Au}$ and Cheng (2012) - focused on the use of airline systems and its influence on employee satisfaction levels - or that of Stamolampros et al. (2019), who examined the key factors regarding satisfaction in tourism-related work through the opinions of employees expressed on social networks. 
Engagement/Socialization. One of the most important concerns within HR is to ensure the commitment of employees to their firm, which very often relates to a correct socialization process. This issue is addressed in 4 articles that reflect how ICTs can favor workers' engagement and socialization. For instance, Kim and Gatling (2018) analyzed the extent to which hospitality sector workers take advantage of virtual socialization platforms, while Janta and Ladkin (2013) and Janta et al. (2012) showed how online social networks can catalyze socialization for immigrant workers in the tourism sector.

Cyberslacking. 3 articles address the issue of cyberslacking. This term refers to the use of ICTs by employees for purposes alien to their job during their work hours. Despite enterprises' regulations, this increasingly present problem leads to work hour losses in tourism firms. Davidson and Ou (2017), Ip et al. (2011) and Rosa and Hastings (2016), amongst others, have analyzed this phenomenon.

Turnover. The use of certain ICTs may influence the turnover rate of tourism sector enterprises, as shown by Li et al. (2019) on Artificial Intelligence and Robotics, or Yuang et al. (2018) about social media as a promotion and sales channel. On other occasions, technologies - like social networks - are a useful platform to understand the elements determining turnover in the tourism sector, as the study of Stamolampros et al. (2019) illustrates.

eWOM. The area of employee Electronic Word of Mouth also appears in 2 works which describe how employees use social networks to disseminate their work-related opinions and the extent to which this may affect the enterprise. Thus, Melián-González and Bulchand-Guidumal (2017a) explained that the comments about their jobs that hotel employees post on social media will probably influence customers' perceptions and attitudes towards those establishments. In turn, Stamolampros et al. (2019) presented eWOM as a potentially important source of information to understand employees' level of satisfaction with their working positions as well as the factors explaining turnover rates.

Change Agent. Employees are an essential agent for introducing innovations in the enterprise - an issue that two articles deal with. Kandampully et al. (2016) acknowledged the role played by the staff as a key agent of innovation and creativity in the hospitality sector, and Nisbet (2009) explained how employees are essential when persuading customers to use technologies in the casino industry.

Digital DIY. The user-friendliness of ICTs very often encourages users to build tailor-made technological solutions without asking the ICTs department, ignoring the rules that the department imposes on users (Davidson and Ou, 2017).

Papers about Technology and Employees show workers' behavior regarding technology. Instead of describing the enterprise's actions, these studies focus on how the worker reacts, behaves, and feels when faced with ICTs. New technologies are likely to increase employees' level of satisfaction; by way of example, Kasavana (1982) analyzed the extent to which invoicing systems improved the morale of employees thanks to the lower number of disputes with customers, who now received a better service. If workers find that using technology is worth it considering the results obtained, then they will be happy to use it. Sectors such as airlines have reported an increased level of satisfaction amongst employees, which is important as any worker frustration or unhappiness would inevitably lead to negative impacts on customer experience (Au and Cheng, 2012).

Employees may also feel so dissatisfied with technology that they resign ( $\mathrm{Li}$ et al., 2019; Stamolampros et al., 2019; Yuan et al., 2018). TAM, and the models derived from it, provide an overview of the different factors determining the acceptance of technologies by employees in various jobs (Lam et al., 2007; Kimes, 2008; Kim et al., 2008; Hu et al., 2009; Kim et al., 2010, Cheng and Cho, 2011, Kim and Gatling, 2018; Sun, et al., 2019). 
ICTs are also likely to foster employees' engagement and socialization, this being a deterrent for turnover intentions. On some occasions, engagement platforms are offered by the firm itself. Examples include VEEP (Virtual Employee Engagement Platform) systems (Kim and Gatling, 2018) or the enterprise's Intranets (Chu and Chu, 2011).

Nonetheless, this engagement becomes consolidated through social networks alien to the firm where employees seek support (Janta and Ladkin, 2013, Janta et al., 2012). Employees often decide to use ICTs on their own, completely ignoring the firm and its ICT department (Digital DIY - Davison and Ou, 2017) or to waste time with technologies on things unrelated to their job (Cyberslaking - Rosa and Hastings, 2016; Ip et al., 2011).

The worker also has the possibility to become a Change Agent through technology, for instance, by promoting its use with customers (Kandampully et al., 2016, Nisbet, 2009). They can even feel tempted to inform the outside world about what is happening inside their enterprise by expressing their views on online social networking sites (eWOM - Stamolampros et al., 2019; Melián-González and Bulchan-Gidumal, 2017a).

\section{b) Technology \& HR Processes}

Training. Articles about Training stress how learning and training can be improved or ICT-based in tourism. For instance, Ravichandram et al. (2015) analyzed the training needs of older workers in the catering sector, together with their perceptions about the role of ICTs in their learning processes. Lema and Agrusa (2009) examined the connection between the use of the World Wide Web by employees and their predisposition towards self-guided learning. Kim et al. (2011) focused on how soft knowledge can be acquired through e-learning in hotels.

Staff Recruitment and Selection. ICTs can be useful for numerous business functions and their power as a recruitment source is a frequently exploited capability. Thus, Madera (2012) focused on how job applicants in the hotel sector react to the utilization of social media as a staff selection method. Mejía and Torres (2018) explained that with the increased use of software platforms for hotel hiring purposes there is a need to analyze and give advice on how to perform video interviews.

Knowledge Management. This business philosophy which links employees' knowledge with the knowledge they need to utilize ICTs as a repository and a means of knowledge transmission, was the main concern in the studies of $\mathrm{Ou}$ et al. (2016) and Sigala and Chalkiti (2015).

Diversity Management. Human Resource Management faces the problem of handling diversity when they address staff with different nationalities, cultures, or backgrounds. ICTs can help them with this task as illustrated in two articles. Gröschl (2011) showed the potential of hotel corporate websites as an effective tool to disseminate diversity management policies; and Harris and Bonn (2000) described how ICTs can facilitate the training of workers with varied cultural, ethnic or religious backgrounds.

Articles dedicated to Technology \& HR Processes relate to processes inherent to the field of Human Resources. Technology has been introduced in every HR administrative system and is seemingly able to fully perform a large number of comprehensive HRM functions (Davidson et al., 2011). ICTs were already operational within the HR area in the 1980s; by way of example, interactive video was used in training (Harris, 1988). Unfortunately, the most traditional training schemes still prevailed in the early 21 st century (Furunes, 2005) to the detriment of other more up-to-date ones. However, Harris and Boom (2000) predicted the possibility of technological diversity 
applied to training to cope with workers' cultural and linguistic diversity, thus improving Diversity Management levels.

Self-directed learning provides employees with more opportunities to practice making decisions as well as to strengthen their critical thinking skills (Lema and Agrusa, 2009). Soft skills could likewise be developed using e-learning programs (Kim et al., 2011). Online social networks and online forums offer workers the chance to receive online training (Janta et al., 2012).

Recruitment and selection procedures have also largely benefited from using ICTs. Gibson and Swift (2011) warned about the mistake committed by cruise companies when they make their websites very appealing to customers but fail to focus on prospective employees. Websites are an excellent place to show what is done on a cruise ship, or in any other tourism enterprise, and thus attract the best candidates for a job. Organizations have also been using online social networks for selection processes during the past decade. However, there is a risk that applicants might perceive these practices as unfair and even as a privacy violation (Madera, 2012). Numerous firms use Asynchronous Video Interviews (AVIs) during their selection processes (Torres and Mejía, 2017, 2018). Such interviews are especially suitable during the initial stages of the costly recruitment processes for management posts, since the best candidates could pass directly to the inperson interview.

Online social media can not only foster creativity amongst employees but also encourage creative processes by helping them share their knowledge. These networks have the potential to enrich Knowledge Management by combining employees according to their different leadership capacities, personality, or educational background - thus building teams capable of finding creative solutions to business problems such as innovation, customer complaint management or new service development, to quote but a few (Sigala and Chalkiti, 2015). Interactive systems have similarly proved helpful to share knowledge in hotels and knowledge-intensive organizations should care more about developing an environment that can foster knowledge sharing (Ou et al., 2016).

\section{c) Technology \& Results}

Success Factors. The 8 articles which deal with Success Factors in the tourism context do not necessarily relate ICTs directly to Human Resources; instead, they see both factors as priorities to reach success. This applies to the study of Yadegaridehkordi et al. (2018) where attention was paid to critical success factors for the Malaysian hotel industry or that of Kandampully et al. (2016), who tried to identify the key success factors when implementing innovation and creativity in hotels.

Performance. A total of 5 articles associate ICTs with enterprise or Human Resource performance in tourism. These studies are necessary, since the productivity paradox points out that, despite appearing everywhere, ICTs are not positively reflected in firms' results (Brynjolfsson and Hitt, 1998). For this reason, Yuan et al. (2018) analyzed the impact that the utilization of social media for advertising purposes has on the performance of travel agency workers; and Tavitiyaman et al. (2011) came to the conclusion that hotels with a strong Human Resource and ICT strategy outperform those whose strategy is not so solid. Similarly, Melian-González and Bulchan-Guidumal (2017b) looked at the role played by ICTs in hotel sector employees' performance.

Costs/Efficiency. The implementation of technologies in general, or more precisely of ICTs, initially pursued very specific and limited outcomes, including improved efficiency in production processes and a reduction of costs. This issue addressed in the oldest article examined (Kasavana, 1982) - continues to arouse interest as proven by its appearance in another much more recent work (Ahmad and Scott, 2019). 
When it comes to Technology \& Results, articles revolve around firm results either through overall firm performance, that of the HR department or the performance achieved by the employees themselves (Yuan et al., 2018) - whether it is pursing the enterprise's success (Chungarande and Saaman, 2018) or that of tourism destinations (Pikkemaat et al., 2018) or even seeking efficiency through cost control (Ahmad and Scott, 2019).

Berger et al. (1993) predicted the importance of HR Management as a success factor for hospitality sector enterprises thanks, amongst other things, to adopting new technologies. Less than twenty years later, Tavitiyaman et al. (2011) stated that HR- and ICT-linked competitive strategies decisively influence hotel performance. These same authors concluded in a later work (Tavitiyaman et al., 2012) that, whereas HR strategies directly impact on behavioral performance, ICT-related strategies affect financial performance. Similarly, Cohen and Olsen (2013) found that the best performing hospitality establishments are those with more satisfied employees and better ICT resources.

Systems like CRM allow firms to both increase customer loyalty and improve long-term profits. This requires not only suitable technology but also employees who share a culture and a set of values that they can use to meet customers' needs through technology (Rahimi, 2017). Employees must be able to surprise customers by offering the kind of attention that a machine is unable to provide, but ICTs can help enhance employees' performance (Melián-González and Bulchand-Gidumal, 2017b).

\section{d) Technology \& Organizational Structures}

The Contents and Knowledge related to jobs which may be influenced or modified due to ICT utilization are addressed in 9 articles. The conclusions in this regard are contradictory; some studies highlight that ICTs will most probably enrich the contents of working positions. By way of example, using ERP is likely to make jobs more fulfilling and challenging, according to the study undertaken by Benders et al. (2009) about the hotel industry. Nonetheless, other works, such as that of Hjalager (1999), point out that introducing more technologies might reduce the need for knowledge and skills in the catering sector and that the availability of more opportunities to improve empowerment levels might be exclusively restricted to the managerial level.

Technohumans. Every day we witness the emergence of technologies which more and more closely imitate the human being; and this holds true for tourism. We are speaking about wearable technology incorporated into some part of the body (tourism employees in this case) which interacts with the user (such as smart glasses or digital bracelets), or even about robots. This topic was covered in 3 articles, namely Yu and Ngan (2019) — about the utilization of robots in hotels - and Wu et al. (2015) - dedicated to wearable technology - and Sigala (2018), who reflected on how robots and other technologies can deliver services similar to those provided by a human employee.

Post/Department Destruction. There is also one article (Woods, 1999) which predicts that ICT introduction may entail the destruction of jobs or of the Human Resource Department — eventually replaced by outsourcing and technology.

Articles dealing with Technology \& Organizational Structures - the least abundant ones - examine the organizational changes generated as a result of ICT incorporation, i.e. the extent to which ICTs modify workplaces, their contents, or the knowledge needed by workers to perform their tasks (Buchanan and McCalman, 1988). Thus, some restaurants have found that adopting certain technologies makes operational work move towards suppliers and enriches their in-house work (Hjalager, 1999). Employees can even make more decisions thanks to the greater availability of control 
mechanisms (Benders et al., 2009). As a negative consequence, the fear always exists that technology might eventually eliminate jobs - those most typically associated with routine hotel tasks, for example (Solnet et al., 2016) — or even replace the HR department (Woods, 1999). Included in this section are jobs involving a new type of employee, the so-called "technohumans" (Robots, Artificial Intelligence, Wearable Technology...), a term which refers to the employees of the future, or of this very moment, e.g. robots (Yu and Ngan, 2019), or to human workers "enhanced" by the capacities supplied by wearable technology (Wu et al., 2015).

As for the evolution of the topics covered over time, the oldest ones are arguably job destruction caused by ICTs, impact of ICTs on costs and efficiency, employees' satisfaction, success factors, and influence exerted by ICTs on job-related contents as well as on recruitment and selection processes. However, most themes have only been dealt with recently, from 2010 onwards, including digital DIY, knowledge management, eWOM, cyberslacking, turnover, technohumans, engagement and socialization, as well as the influence on performance.

\subsubsection{Technologies}

Table 3 lists the technologies analyzed in the different works. Since any given article may address the use of more than one technology, the classification offered in the table was made according to the most up-to-date and/or complex:

-ICTs in General. A large proportion of the articles examined (33) do not deal with a particular technology; instead, they refer to ICTs in general, as exemplified by the works of Harris (1995) or Sigala (2018).

-Internet/Websites. A total of 7 articles focus on the Internet or on websites. Examples are those written by Chu and Chu (2011), Abellá Garcés et al. (2004) and Gibson and Swift (2011) on selection, training or socialization functions.

-Social Networks. A significant number of works (6 articles) focus on social networking sites and their use in tourism, e.g. Madera (2012), Yuan and Zeng (2018), and Sigala and Chalkiti (2015) - focused on staff selection, knowledge management and employee advertising. The Glassdoor platform is a stand out network and was conceived to allow workers to express comments about their work centers. It has become a real barometer both of employees' well-being and of satisfaction with their firms (Stamolampros et al., 2019).

-Video. Only 3 works covered the use of video as a technology in the tourism sector, namely those of Harris (1988), Torres and Mejía (2017) and Mejía and Torres (2018), illustrating the use of video in selection, interviews or training processes.

-Robotics/Artificial Intelligence. 2 articles revolve around Artificial Intelligence or Robotics and their utilization in tourism. Li et al., (2019) on whether using this technology in hotels might affect staff turnover rates and Yu and Ngan (2019) on the differences between customers' perceptions about services provided by robots or by human employees. The fact that only two papers about robotics and AI were found in this systematic review stems from our way of collecting reviewable articles. This is undoubtedly one of the research areas with a brighter future in Tourism, as proven by recent systematic literature reviews in AI and robotics (Lu et al., 2020).

-Front Office Systems enable the enterprise to contact its end users, and are examined in 2 articles: Kim et al., (2008) analyzed the factors underlying the acceptance of front office systems in hotels using the TAM model, whereas Shin et al. (2019) explored the effects associated with innovation processes in such systems. 
Finally, 7 articles refer to other technologies, including airline Information Systems, Employee Engagement Platforms, ERP systems, kitchen display systems, payment systems, mobile technology, and wearable technology.

Regarding the evolution over time, it is worth highlighting that ICTs in general have been dealt with during every period, and video technology also appears as a mature technology, as opposed to Social Networks, Robotics, and Artificial Intelligence, whose use started as recently as 2010 .

\subsection{Authors and Countries}

Only 12 out of 60 articles analyzed were written by a single author, most works (48) resulting from co-authorship. Table 4 lists the most prolific authors and their universities, together with the countries where their universities are located. $\mathrm{N}$ was taken as the number of times an author has published a work, either as a co-author or alone, and regardless of the signing order in co-authorship cases.

INSERT TABLE 4

The University was recorded as the one where the author worked when each article appeared, the country being that in which the university is located. Therefore, $\mathrm{N}$ shows how many times a researcher from a country has published an article and reflects how prolific each country is in terms of articles, researchers, or both. It can be seen that, although Professor Rob Law is the most prolific scholar, and that he works at Hong Kong Polytechnic University (China), the United States has published the most articles in this field, followed by China, the United Kingdom, South Korea, and Spain.

\section{Conclusions, Implications, Limitations, and Future Research 4.1. Conclusions}

Although there are several previous reviews of the literature on Human Resource Management in tourism (Davidson et al., 2011) and ICTs (Ip et al., 2011, Law et al., 2018), none of them has jointly examined the two topics; here lies the most important contribution made with this work. Our systematic review took as its reference the articles published in renowned journals indexed in the Web of Science and belonging to the fields of Tourism, Information Systems, and Human Resources.

Most of the articles analyzed come from Tourism journals, only very few appearing in journals specialized in Human Resources and Information Systems. A first conclusion would be that further research still remains to be done both in journals about Human Resources and in those dedicated to Information Systems concerning these issues, where tourism can prove to be a very fruitful study niche.

Furthermore, the research on this subject matter is very recent, as hardly any articles about this topic appeared prior to 2010. This finding matches those obtained in previous studies that reveal a growing interest in ICT-related themes within the tourism sector during the past decade (González et al., 2019).

The works examined applied different research methods, empirical clearly outnumbering theoretical articles. Amongst the empirical studies the use of survey-based field studies stands out, followed by interview-based case studies. It can also be clearly seen that the proportion of empirical works has steadily increased over time, to the detriment of theoretical articles. This reveals that, as the study of this area progresses, scholars have moved away from speculating about reality to analyzing it more directly.

Despite the widespread utilization of statistical techniques for data analysis purposes in the articles under study, a considerable number of them use no statistical techniques whatsoever. Instead they follow the lines of merely theoretical articles either structured around case studies or based on interviews - which provide valuable 
information that cannot be ignored. Nevertheless, amongst those which do use statistical techniques stand out the articles which resort to multivariate analyses and, above all, those applying SEM/PATH models - particularly popular in recent years. This clearly suggests that research in this field currently has a higher degree of sophistication.

The United States, followed at quite some distance by China and then by South Korea, are the countries on which the empirical part of the works examined most frequently focuses.

\subsection{Theoretical Implications}

A relevant contribution made with this work is the study of issues addressed in the articles examined: Recruitment/Selection, Training, Job-related Contents/Knowledge, TAM, Success Factors, Performance, Employees' Satisfaction, Engagement/Socialization, Technohumans, Turnover, Cyberslacking, Change Agent, eWOM, Knowledge Management, Costs/Efficiency, Digital DIY, and Post/Department Destruction. An open list was adopted to classify them, i.e., new topics have gradually appeared as we analyzed more articles. The most important topics according to the attention received were: ICT use in Recruitment/Selection processes, ICT-based Training, the extent to which Job-related Contents and Knowledge are affected by technologies, the relevance of the TAM model and its derivatives when it comes to explaining the adoption of new technologies by employees, and ICTs and Human Resources as Success Factors in tourism sector enterprises.

Although most of the topics covered have acquired greater significance during the last decade, new areas such as Digital DIY, Knowledge Management, eWOM, Cyberslacking, Turnover and its link to ICTs, Technohumans, the degree of Engagement and Socialization which may be positively or negatively affected by ICT utilization, and the impact of ICTs on staff performance, especially deserve the academic community's attention and should open important study paths in the near future.

The topics under study were grouped together into 4 broad areas, Technology \& Employees having received the most attention so far. Despite mainly including research studies on how employees behave in relation to technology, a special mention must be made of the works that follow the Technology Acceptance Model (TAM) within this field (which hardly appears during the first period analyzed as opposed to its growing relevance in the last decade).

The second area - Technology \& HR Processes - includes studies aimed at identifying which HR functions rely to a greater extent on technologies. Even though the answer to that question today would be all functions, the traditional ones associated with training, recruitment and selection arouse the attention of more researchers.

Technology \& Results brings together the works centered on results of an economic nature which, although very important, do not receive as much attention as they probably should. Finally, the least analyzed area is Technology \& Organizational Structure, focused on how structures and work positions in the tourism industry change after the introduction of technologies. A relevant contribution made with this work lies in the distribution of the literature about ICTs and Human Resources in Tourism across the aforesaid four areas.

Even if a large proportion of the articles analyzed revolve around ICTs in general without focusing on specific technologies, a considerable number of works deal with Social Media, as well as with Tourism Websites and the Internet. Note that Social Networks - the same as robotic technology — have only started to arouse interest lately. Wearables stand out as another type of technology which have received very little attention so far but should be addressed in future research works. 
Despite analyzing articles from 73 journals framed within three different areas and seeking information from the JCR index 2018 in the areas of Hospitality, Leisure, Sports and Tourism (27 journals), Management (31 HR journals), and Information Systems (15 journals), and although no search date was defined in the methodology, only 60 articles were found to combine the topics of ICTs and HR within the tourism context. Expressed differently, researchers find themselves with a broad domain to work on, insofar as the implications linked to ICTs are not only essential for Human Resource management as a whole but they also play a key role in the tourism industry.

Even though a professor who works at Hong Kong Polytechnic University is the most prolific author, the United States is the country with the highest number of articles published. This finding, which should come as no surprise considering the supremacy of Anglo-Saxon countries in studies related to ICTs, follows the trail of previous publications (González et al., 2019).

\subsection{Practical Implications}

The analysis of the topics highlighted in this article shows domains where ICTs can prove useful for tourism firms in Human Resources. Besides the applications most commonly used in training processes, or in staff recruitment and selection, it is worth stressing the role which these technologies can play as a tool to attain workers' engagement and socialization, making it possible to instill the business culture into new employees. Attention must likewise be paid to how employees use social media either to communicate with their colleagues, to spread information about the firm's activities and services, or to express their opinion about the latter - using platforms such as Glassdoor.

The Community Manager has a key function in this respect, should employees post a negative opinion about their employers that might prove detrimental to new incorporations into the staff or even harmful to business reputation.

It has also been emphasized that workers transgress firm policies in order to move ahead in the field of technological DIY, or to apply technology to uses other than those planned by the enterprise, thus entering the context of Cyberslacking. Both Human Resource and ICT departments must bear in mind that the user-friendliness and accessibility of technology pose new temptations for workers; hence the need for them to lay down regulations in that respect which are flexible enough to not limit their employees' creativity. As suggested by Kandampully et al. (2016), the combination of human beings and technologies represents a hybrid organization model which ensures that firms will improve their internal as well as external resources. What matters is to not invest in one of these factors without considering the effects on the other. ICTs bring opportunities to foster ideas, feedback, and all sorts of useful information from employees. The latter are a highly valuable internal resource: they constitute the organization's pulse. For this reason, enterprises must provide the services required to build a suitable climate and culture to boost creativity and energy amongst their employees.

Some of the applications analyzed in the articles under study and collected in the Key Findings (Table 5) include: Engagement Platforms, Online Social networks where employees could show their opinions, Robots to interact with customers, e-Commerce systems, Hotel Front Office systems, ERP systems, Point-of-Sale systems, Intranets for socialization purposes, Online Forums for socialization, Online Travel Agents or Wearable Technology. Despite belonging to areas other than HRs, all such applications impact on HRM. Therefore, tourism firm managers, especially those who develop their professional activity in ICT and HR areas, should consider the extent to which these 
applications affect employees, seeking to minimize their perverse effects and, conversely, to fully exploit their potential.

\subsection{Limitations and Future Research}

This work focused on analyzing the literature about ICTs and Human Resources in tourism through the research works published in academic journals; hence our decision not to examine books or papers presented at conferences, following along the lines of previous literature reviews (Law et al., 2014). The search was limited to 73 academic journals, although the sources analyzed are still highly representative. The articles examined come from three areas - a) Hospitality, Leisure, Sport and Tourism; b) Management; and c) Information Systems - although we could have also found papers dealing with Tourism, Human Resources, and ICTs in other areas - e.g. Hospitality Education. This limitation with regard to the examined works which is inherent to any literature review has appeared in previous similar studies. By way of example, Leung et al. (2015) and Ip et al. (2011) based their literature review studies on 8 journals, while Law et al. (2013) used only one journal. We are fully aware that works which may be of interest in this research field have not been examined because of our way of selecting the articles to be analyzed, e.g. the study authored by Lu et al. (2020) which offers a thorough analysis about the use of robots through a literature review, though focusing on the service sector.

Despite the above, this work can prove helpful both in the academic field and for tourism firm managers. It is especially relevant for those who develop their professional activity in ICTs and Human Resources, since topics and technologies have appeared which can open new research paths, together with innovative conceptions about technologies and their application to human resources in the tourism sector.

The topics which open important paths for research include some of the least often studied, amongst them: diversity through the use of technologies, talent attraction, and legal issues raised by technologies. Despite their importance, the latter have hardly ever been dealt with in the literature under study. Issues such as the regulation of ICT utilization by employees for private purposes, the blurred boundaries between digital and work-related private life or the violation of workers' privacy by firms through ICTs deserve a more in-depth analysis. Since robotics and artificial intelligence can displace humans in some tasks, research should delve deeper into aspects like employees' reluctance to using these technologies (Law et al, 2020). Other technologies which have only been insufficiently covered by a few papers should receive more attention in the future. From our point of view, Wearables and Social Networks emerge as the technologies which, due to their novelty, guarantee a longer research path for the coming years. As for Robotics and Artificial Intelligence, they have been studied from the customer's perspective rather than from that of the employee (Tung and $\mathrm{Au}, 2018$ ). Finally, big data as a basic information resource for tourism employee management purposes also stands out as a topic which remains in need of more thorough examination.

\section{References}

Abellá Garcés, S.A., Gorgemans, S., Martínez Sánchez, A., and Pérez Pérez, M. (2004), "Implications of the Internet - An analysis of the Aragonese hospitality industry, 2002", Tourism Management, Vol. 25 No. 5, pp. 603-613.

Ahmad, R., and Scott, N. (2019), "Technology innovations towards reducing hospitality human resource costs in Langkawi, Malaysia", Tourism Review, Vol. 74 No. 3, pp. 547-562.

Ali, F., Park, E. (O.), Kwon, J. and Chae, B. (K.) (2019), "30 years of contemporary hospitality management: Uncovering the bibliometrics and topical trends", International Journal of Contemporary Hospitality Management, Vol. 31 No. 7, pp. 2641-2665. 
$\mathrm{Au}, \mathrm{N}$., and Cheng, T.C.E. (2012), "The formation of employee satisfaction with airline information systems", Journal of Travel \& Tourism Marketing, Vol. 29 No. 4, pp. 335-351.

Benders, J., Schouteten, R., and Aoulad el Kadi, M. (2009), "ERP-systems and job content: a case study of HR-assistants", Personnel Review, Vol. 38 No. 6, pp. 641-654.

Berger, F., Fulford, M.D., and Krazmien, M. (1993), "Human resources management in the 21st century: Predicting partnerships for profit", Journal of Hospitality \& Tourism Research, Vol. 17 No. 1, pp. 87-102.

Brynjolfsson, E., and Hitt, L.M. (1998), "Beyond the productivity paradox", Communications of the ACM, Vol. 41 No. 8, pp. 49-55.

Buchanan, D.A., and McCalman, J. (1988), "Confidence, visibility and pressure: The effects of shared information in computer aided hotel management. New Technology", Work and Employment, Vol. 3 No. 1, pp. 38-46.

Chan, H. C., Guness, V., and Kim, H.W. (2015), "A method for identifying journals in a discipline: An application to information systems", Information \& Management, Vol. 52 No. 2, pp. 239-246.

Cheng, S., and Cho, V. (2011), "An integrated model of employees' behavioral intention toward innovative information and communication technologies in travel agencies", Journal of Hospitality and Tourism Research, Vol. 35 No. 4, pp. 488-510.

Chingarande, A. and Saayman, A. (2018), "Critical success factors for tourism-led growth", International Journal of Tourism Research, Vol. 20 No. 6, pp. 800-818.

Chu, A.Z.C., and Chu, R.J.C. (2011), "The intranet's role in newcomer socialization in the hotel industry in Taiwan-technology acceptance model analysis", The International Journal of Human Resource Management, Vol. 22 No. 5, pp. 1163-1179.

Cohen, J.F., and Olsen, K. (2013), "The impacts of complementary information technology resources on the service-profit chain and competitive performance of South African hospitality firms", International Journal of Hospitality Management, Vol. 34 No. 1, pp. 245-254.

Davidson, M.C.G., McPhail, R., and Barry, S. (2011), "Hospitality HRM: Past, present and the future", International Journal of Contemporary Hospitality Management, Vol. 23 No, 4, pp. 498-516.

Davison, R.M., and Ou, C.X.J. (2017), "Digital work in a digitally challenged organization", Information \& Management, Vol. 54 No. 1, pp. 129-137

Everard, A., Pierre, K.S., and Heck, J. (2017), "Contributors to the High-impact IS Journals (1977-2014): An Aid for Setting Research Standards", Communications of the AIS, Vol. 40 No. 4, pp. 53-81.

Furunes, T. (2005), "Training paradox in the hotel industry", Scandinavian Journal of Hospitality and Tourism, Vol. 5 No. 3, pp. 231-248

Gibson, P., and Swift, J. (2011), "e2c: Maximising electronic resources for cruise recruitment", Journal of Hospitality and Tourism Management, Vol. 18 No. 1, pp. 61-69.

Gomezelj, D. O. (2016), "A systematic review of research on innovation in hospitality and tourism", International Journal of Contemporary Hospitality Management, Vol. 28 No. 3, pp. 516-558.

González, R. Llopis, J., and Gascó, J.(2013), "Information Systems Offshore Outsourcing: Managerial Conclusions from Academic Research", International Entrepreneurship and Management Journal, Vol. 9 No. 2, pp. 229-259.

González, R., Gascó, J., and Llopis, J. (2019), "ICTs in Hotel Management: A Research Review", International Journal of Contemporary Hospitality Management, Vol. 31 No. 9, pp. 3583-3609.

Gröschl, S. (2011), "Diversity management strategies of global hotel groups: A corporate web site-based exploration", International Journal of Contemporary Hospitality Management, Vol. 23 No. 2, pp. 224-240

Harris, K.J. (1995), "Training technology in the hospitality industry: A matter of effectiveness and efficiency", International Journal of Contemporary Hospitality Management, Vol. 7 No. 6, pp. 24-29.

Harris, K.J., and Bonn, M.A. (2000), "Training Techniques and Tools: Evidence from the Foodservice Industry", Journal of Hospitality and Tourism Research, Vol. 24 No. 3, pp. 320-335. 
Harris, K.J. (1988), "Employee training: Using high tech and videodisc technology", Journal of Hospitality and Tourism Research, Vol. 12 No. 2, 115-125.

Hart, C. (1998), Doing a Literature Review: Releasing the Social Science Research Imagination. Sage Publications. London.

Hjalager, A. M. (1999), "Technology domains and manpower choice in the restaurant sector", New Technology, Work and Employment, Vol. 14 No. 1, pp. 62-74.

Huh, H.J., Kim, T. (T.), and Law, R. (2009), "A comparison of competing theoretical models for understanding acceptance behavior of information systems in upscale hotels", International Journal of Hospitality Management, Vol. 28 No. 1, pp. 121-134.

Hung, K., and Law, R. (2011), "An overview of internet-based surveys in hospitality and tourism journals", Tourism Management, Vol. 32 No. 4, pp. 717-724.

Inversini, A., and Masiero, L. (2014), "Selling rooms online: The use of social media and online travel agents", International Journal of Contemporary Hospitality Management, Vol. 26 No. 2, pp. 272-292.

Ip, C., Leung, R., and Law, R. (2011), "Progress and development of information and communication technologies in hospitality", International Journal of Contemporary Hospitality Management, Vol. 23 No. 4, pp. 533-551.

Iyengar, K., and Balijepally, V. (2015), "Ranking journals using the dominance hierarchy procedure: an illustration with IS journals", Scientometrics, Vol. 102 No. 1, pp. 5-23.

Janta, H., and Ladkin, A. (2013), "In search of employment: online technologies and Polish migrants", New Technology, Work and Employment, Vol. 28 No. 3, pp. 241-253.

Janta, H., Lugosi, P., Brown, L., and Ladkin, A. (2012), "Migrant networks, language learning and tourism employment", Tourism Management, Vol. 33 No. 2, pp. 431-439.

Jiang, L., Jiang, D., and Grover, V. (2017), "The Sphere of Influence of Information Systems Journals: A Longitudinal Study", Communications of the Association for Information Systems, Vol. 41, pp. 150-178.

Kandampully, J., Bilgihan, A., and Zhang, T.C. (2016), "Developing a people-technology hybrids model to unleash innovation and creativity: The new hospitality frontier", Journal of Hospitality and Tourism Management, Vol. 29, pp. 154-164.

Kandampully, J., Zhang, T., and Jaakkola, E. (2018), "Customer experience management in hospitality: A literature synthesis, new understanding and research agenda", International Journal of Contemporary Hospitality Management, Vol. 30 No. 1, pp. 21-56.

Kasavana, M.L. (1982), "Computer-assisted hospitality information systems", International Journal of Hospitality Management, Vol. 1 No. 2, pp. 91-94

Kim, J., Erdem, M., Byun, J., and Jeong, H. (2011), "Training soft skills via e-learning: International chain hotels", International Journal of Contemporary Hospitality Management, Vol. 23 No. 6, pp. 739-763.

Kim, J., and Gatling, A. (2018), "The impact of using a virtual employee engagement platform (VEEP) on employee engagement and intention to stay", International Journal of Contemporary Hospitality Management, Vol. 30 No. 1, pp. 242-259.

Kim, T.G., Lee, J.H., and Law, R. (2008), "An empirical examination of the acceptance behaviour of hotel front office systems: An extended technology acceptance model", Tourism Management, Vol. 29 No. 3, pp. 500-513.

Kim, T.T., Suh, Y.K., Lee, G., and Choi, B.G. (2010), "Modelling roles of tasktechnology fit and self-efficacy in hotel employees' usage behaviours of hotel information systems", International Journal of Tourism Research, Vol. 12 No. 6, pp. 709-725.

Kimes, S.S.E. (2008), "The role of technology in restaurant revenue management", Cornell Hospitality Quarterly, Vol. 49 No. 3, pp. 297-309.

Ladkin, A., and Buhalis, D. (2016), "Online and social media recruitment: Hospitality employer and prospective employee considerations", International Journal of Contemporary Hospitality Management, Vol. 28 No. 2, pp. 327-345.

Lam, T., Cho, V., and Qu, H. (2007), "A study of hotel employee behavioral intentions towards adoption of information technology", International Journal of Hospitality Management, Vol. 26 No. 1, pp. 49-65. 
Law, R., Buhalis, D., and Cobanoglu, C. (2014), "Progress on information and communication technologies in hospitality and tourism", International Journal of Contemporary Hospitality Management, Vol. 26 No. 5, pp. 727-750.

Law, R., Leung, D., Au, N., and Lee, H.A. (2013), "Progress and development of information technology in the hospitality industry: Evidence from Cornell Hospitality Quarterly", Cornell Hospitality Quarterly, Vol. 54 No. 1, pp. 10-24.

Law, R., Leung, D. and Chan, I.C.C. (2020), "Progression and development of information and communication technology research in hospitality and tourism: A state-of-theart review", International Journal of Contemporary Hospitality Management, Vol. 32 No. 2, pp. 511-534.

Law, R., Fong, D.K.C., Chan, I.C.C. and Fong, L.H.N. (2018), "Systematic review of hospitality CRM research". International Journal of Contemporary Hospitality Management, Vol. 30 No. 3, pp. 1686-1704.

Lema, J.D., and Agrusa, J. (2009), "Relationship of WWW usage and employee learning in the casino industry", International Journal of Hospitality Management, Vol. 28 No. 1, pp. 1825 .

Leung, D., Law, R., Van Hoof, H., and Buhalis, D. (2013), "Social media in tourism and hospitality: A literature review", Journal of travel \& tourism marketing, Vol. 30 No. 1-2, pp. 322.

Leung, X. Y., Xue, L., and Bai, B. (2015), "Internet marketing research in hospitality and tourism: A review and journal preferences", International Journal of Contemporary Hospitality Management, Vol. 27 No. 7, pp. 1556-1572.

Li, J.J., Bonn, M.A., and Ye, B.H. (2019), "Hotel employees' artificial intelligence and robotics awareness and its impact on turnover intention: The moderating roles of perceived organizational support and competitive psychological climate", Tourism Management, Vol. 73, pp. 72-181.

Lowry, P., Moody, G., Gaskin, J., Galletta, D., Humphreys, S., Barlow, J., and Wilson, D. (2013), "Evaluating journal quality and the association for information systems (AIS) senior scholars' journal basket via bibliometric measures: do expert journal assessments add value?" MIS Quarterly, Vol. 37 No. 4, pp. 993-1012.

Lu, V.N, Wirtz J., Kunz, W., Paluch, S. Gruber, T. Martins A. and Patterson, P. (2020), "Service robots, customers, and service employees: what can we learn from the academic literature and where are the gaps?" Journal of Service Theory and Practice. Forthcoming.

Madera, J.M. (2012), "Using social networking websites as a selection tool: The role of selection process fairness and job pursuit intentions", International Journal of Hospitality Management, Vol. 31 No. 4, pp. 1276-1282.

Marasco, A., De Martino, M., Magnotti, F. and Morvillo, A. (2018), "Collaborative innovation in tourism and hospitality: a systematic review of the literature", International Journal of Contemporary Hospitality Management, Vol. 30 No. 6, pp. 2364-2395.

Mejía, C., and Torres, E.N. (2018), "Implementation and normalization process of asynchronous video interviewing practices in the hospitality industry", International Journal of Contemporary Hospitality Management, Vol. 30 No. 2, pp. 685-701.

Melián-González, S., and Bulchand-Gidumal, J. (2017a), "Extending the scope of hotel client reactions to employee injustice: Hotel employer reviews on the Internet", International Journal of Hospitality Management, Vol. 63, pp. 93-100.

Melián-González, S., and Bulchand-Gidumal, J. (2017b), "Information technology and front office employees' performance", International Journal of Contemporary Hospitality Management, Vol. 29 No. 8, pp. 2159-2177.

Nisbet, S. (2009), "The role of employees in encouraging customer adoption of new gaming machine payment technologies", International Journal of Contemporary Hospitality Management, Vol. 21 No. 4, pp. 422-436.

Nusair, K., Butt, I. and Nikhashemi, S.R. (2019), “A bibliometric analysis of social media in hospitality and tourism research". International Journal of Contemporary Hospitality Management, Vol. 31 No. 7, pp. 2691-2719. 
Okumus, B., Koseoglu, M.A., and Ma, F. (2018), "Food and gastronomy research in tourism and hospitality: A bibliometric analysis". International Journal of Hospitality Management, Vol. 73, pp. 64-74.

Ou, C.X.J., Davison, R.M., and Wong, L.H.M. (2016), "Using interactive systems for knowledge sharing: The impact of individual contextual preferences in China", Information \& Management, Vol. 53 No. 2, pp. 145-156.

Pikkemaat, B., Peters, M., and Chan, C.S. (2018), "Needs, drivers and barriers of innovation: The case of an alpine community-model destination", Tourism Management Perspectives, Vol. 25, pp. 53-63.

Rahimi, R. (2017), "Customer relationship management (people, process and technology) and organisational culture in hotels: Which traits matter?" International Journal of Contemporary Hospitality Management, Vol. 29 No. 5, pp. 1380-1402.

Ravichandran, S., Cichy, K.E., Powers, M., and Kirby, K. (2015), "Exploring the training needs of older workers in the foodservice industry", International Journal of Hospitality Management, Vol. 44, pp. 157-164.

Rosa, N.B., and Hastings, S.O. (2016), "Texting in their pockets: Millennials and rule violations in the hospitality industry", Journal of Hospitality and Tourism Management, Vol. 29, pp. $33-40$

Shen, Y., Morrison, A.M., Wu, B., Park, J., Li, C., and Li, M. (2018), "Where in the world? A geographic analysis of a decade of research in tourism, hospitality, and leisure journals", Journal of Hospitality and Tourism Research, Vol. 42 No. 2, pp. 171-200.

Shin, H., Perdue, R.R., \& Kang, J. (2019), "Front desk technology innovation in hotels: A managerial perspective", Tourism Management, Vol. 74, pp. 310-318.

Sigala, M. (2018), "New technologies in tourism: From multi-disciplinary to antidisciplinary advances and trajectories", Tourism Management Perspectives, Vol. 25, pp. 151-155.

Sigala, M., \& Chalkiti, K. (2015), "Knowledge management, social media and employee creativity", International Journal of Hospitality Management, Vol. 45, pp. 44-58.

Smith, M. A. \& Kumar, R. L. (2004), "A theory of application service provider (ASP) use from a client perspective", Information \& Management, Vol. 41 No. 8, pp. 977-1002.

Solnet, D., Baum, T., Robinson, R.N., and Lockstone-Binney, L. (2016), "What about the workers? Roles and skills for employees in hotels of the future", Journal of Vacation Marketing, Vol. 22 No. 3, pp. 212-226.

Stamolampros, P., Korfiatis, N., Chalvatzis, K. and Buhalis, D. (2019), "Job satisfaction and employee turnover determinants in high contact services: Insights from Employees' Online reviews", Tourism Management, Vol. 75, pp. 130-147.

Sun, S., Lee, P., and Law, R. (2019), "Impact of cultural values on technology acceptance and technology readiness", International Journal of Hospitality Management, Vol. 77, pp. 89-96.

Tavitiyaman, P., Qiu Zhang, H., and Qu, H. (2012), "The effect of competitive strategies and organizational structure on hotel performance", International Journal of Contemporary Hospitality Management, Vol. 24 No. 1, pp. 140-159.

Tavitiyaman, P., Qu, H., and Zhang, H.Q. (2011), "The impact of industry force factors on resource competitive strategies and hotel performance", International Journal of Hospitality Management, Vol. 30 No. 3, 648-657.

Torres, E.N., and Mejía, C. (2017), "Asynchronous video interviews in the hospitality industry: Considerations for virtual employee selection", International Journal of Hospitality Management, Vol. 61, pp. 4-13.

Tranfield, D., Denyer, D. and Smart, P. (2003), "Towards a methodology for developing evidence-informed management knowledge by means of systematic review", British Journal of Management, Vol. 14, pp. 207-222.

Tung, V.W.S. and Au, N. (2018), "Exploring customer experiences with robotics in hospitality". International Journal of Contemporary Hospitality Management, Vol. 30 No. 7, pp. 2680-2697.

Van Horn, R.L. (1973), "Empirical studies of management information systems. ACM SIGMIS Database: the DATABASE for Advances in Information Systems", Vol. 5 No. 2-3-4, pp. 172-182. 
Woods, R.H. (1999), "Predicting is difficult, especially about the future: Human resources in the new millennium", International Journal of Hospitality Management, Vol. 18 No. 4, pp. 443-456.

Wu, L., Fan, A.A., and Mattila, A.S. (2015), "Wearable technology in service delivery processes: The gender-moderated technology objectification effect", International Journal of Hospitality Management, Vol. 51, pp. 1-7.

Yadegaridehkordi, E., Nilashi, M., Nasir, M.H.N.B.M., and Ibrahim, O. (2018), "Predicting determinants of hotel success and development using Structural Equation Modelling (SEM)-ANFIS method", Tourism Management, Vol 66, pp. 364-386.

Yu, C.-E., and Ngan, H.F.B. (2019), "The power of head tilts: gender and cultural differences of perceived human vs human-like robot smile in service", Tourism Review, Vol. 74 No. 3, pp. 428-442.

Yuan, B., Li, J., and Zeng, G. (2018), "Trapped as a Good Worker: The Influence of Coercive Acquaintance Advertising on Work Outcomes", Cornell Hospitality Quarterly, Vol. 59 No. 4, pp. 428-441.

Zupic, I., and Čater, T. (2015), "Bibliometric methods in management and organization", Organizational Research Methods, Vol. 18 No. 3, pp. 429-472. 
Figure 1: Country on which papers focus

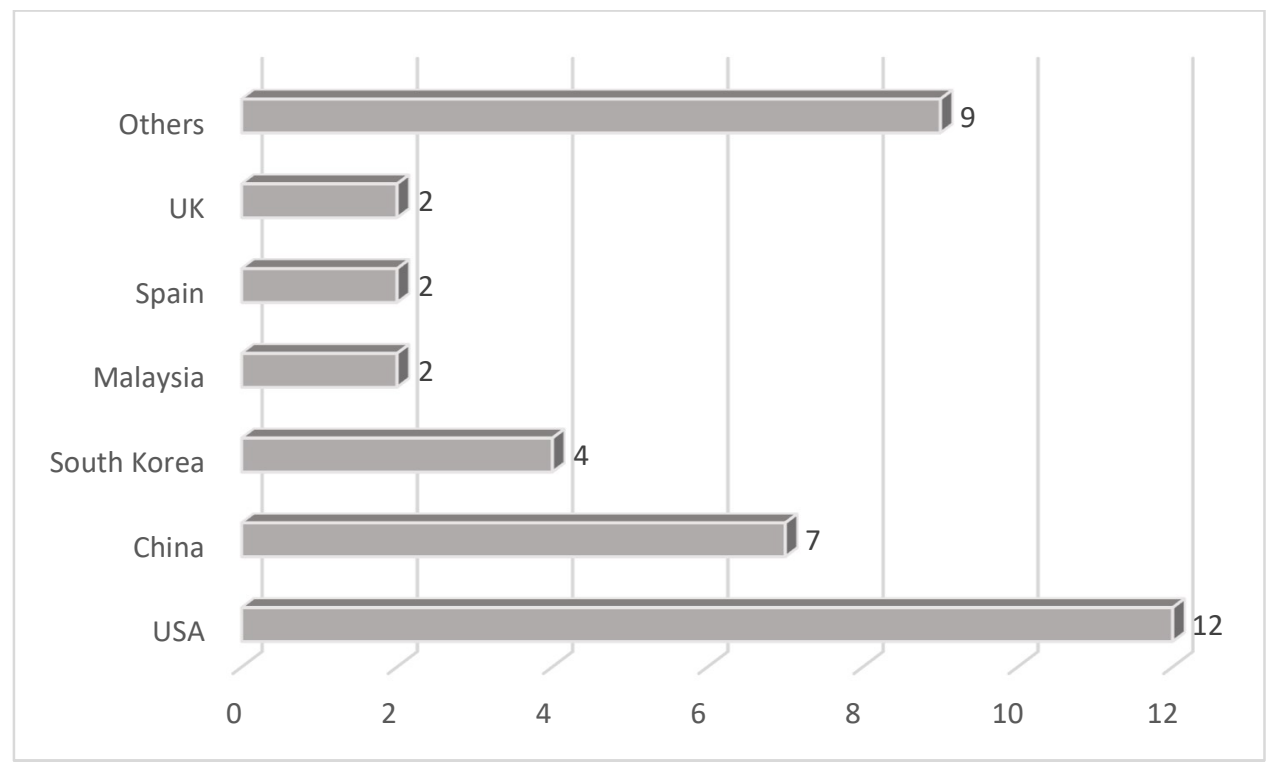

Figure 2: Topics by period

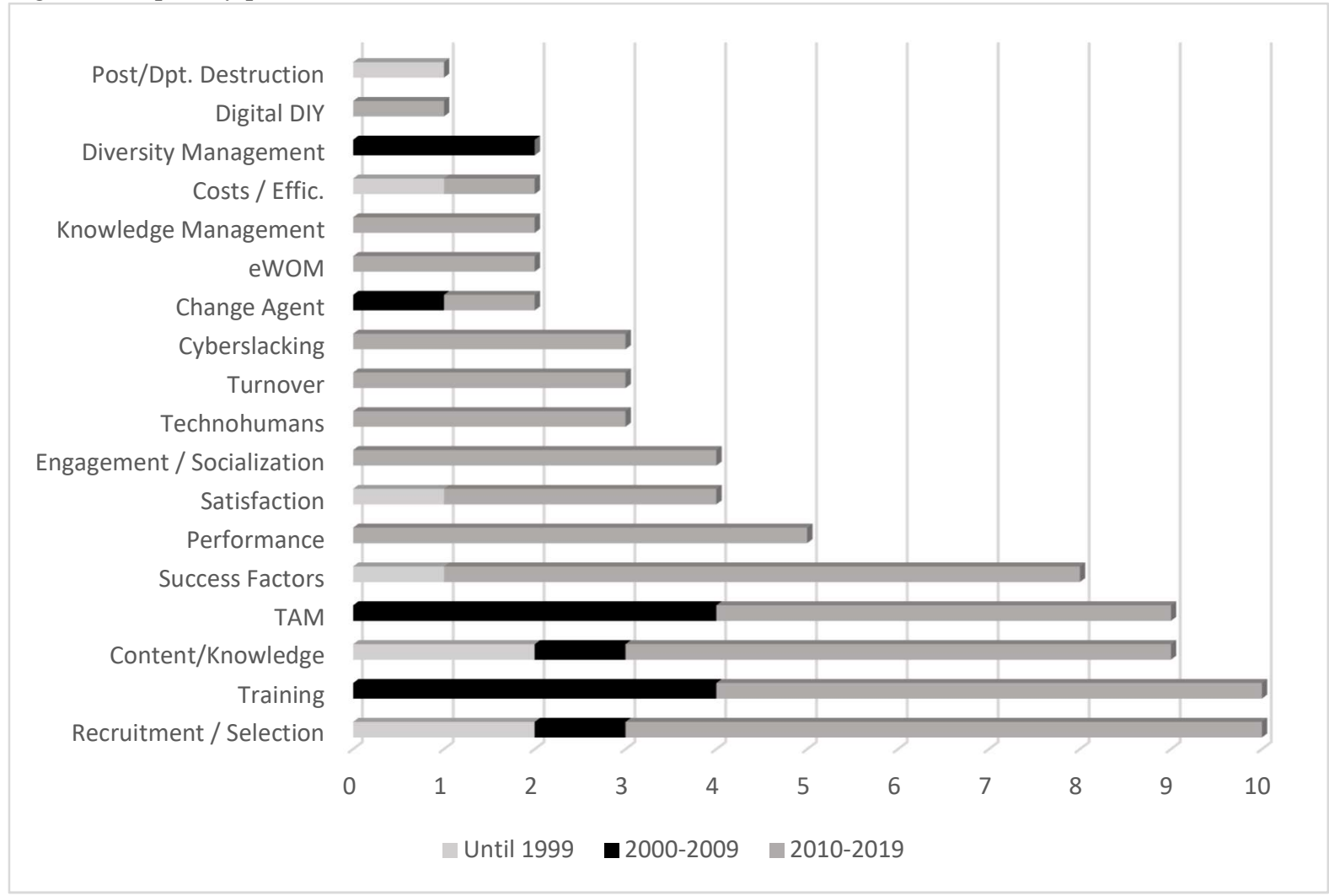


Table 1: Journals and Papers analyzed

\begin{tabular}{|lrr|}
\hline \multicolumn{1}{|c}{ JOURNAL } & $\mathbf{N}$ & \% \\
\hline International Journal of Contemporary Hospitality Management & 14 & 23.3 \\
International Journal of Hospitality Management & 14 & 23.3 \\
Tourism Management & 7 & 11.7 \\
Journal of Hospitality \& Tourism Research & 4 & 6.7 \\
Journal of Hospitality \& Tourism Management & 3 & 5.0 \\
Cornell Hospitality Quarterly & 2 & 3.3 \\
Tourism Management Perspectives & 2 & 3.3 \\
Tourism Review & 2 & 3.3 \\
Journal of Travel \& Tourism Marketing & 1 & 1.7 \\
International Journal of Tourism Research & 1 & 1.7 \\
Journal of Travel \& Tourism Marketing & 1 & 1.7 \\
Journal of Vacation Marketing & 1 & 1.7 \\
Scandinavian Journal of Hospitality \& Tourism & 1 & 1.7 \\
\hline TOTAL TOURISM Journals & $\mathbf{5 3}$ & $\mathbf{8 8 . 3}$ \\
\hline New Technology, Work and Employment & 3 & 5.0 \\
Personnel Review & 1 & 1.7 \\
The International Journal of Human Resource Management & 1 & 1.7 \\
\hline TOTAL HR Journals & $\mathbf{5}$ & $\mathbf{8 . 3}$ \\
\hline Information \& Management & 2 & 3.3 \\
\hline TOTAL IS Journals & $\mathbf{2}$ & $\mathbf{3 . 3}$ \\
\hline
\end{tabular}

Table 2: Research Methodologies and Statistical Techniques by period

\begin{tabular}{|lrrrrrrrr|}
\hline \multicolumn{1}{c|}{ METHODOLOGIES } \\
\hline & Until 1999 & $\mathbf{2 0 0 0 - 2 0 0 9}$ & $\mathbf{2 0 1 0 - 2 0 1 9}$ & & \\
\hline & N. & $\%$ & N. & $\%$ & N. & $\%$ & Total & $\%$ \\
\hline Empirical & $\mathbf{3}$ & $\mathbf{4 2 . 9}$ & $\mathbf{1 0}$ & $\mathbf{9 0 . 9}$ & $\mathbf{3 8}$ & $\mathbf{9 0 . 5}$ & $\mathbf{5 1}$ & $\mathbf{8 5 . 0}$ \\
\hline Field Study/surveys & 2 & 28.6 & 7 & 63.6 & 17 & 40.5 & 26 & 43.3 \\
Case Study/Interviews & 1 & 14.3 & 2 & 18.2 & 8 & 19.0 & 11 & 18.3 \\
Experiments & 0 & 0.0 & 0 & 0.0 & 4 & 9.5 & 4 & 6.7 \\
Literature Review & 0 & 0.0 & 0 & 0.0 & 4 & 9.5 & 4 & 6.7 \\
Content Analysis & 0 & 0.0 & 1 & 9.1 & 2 & 4.8 & 3 & 5.0 \\
Content Analysis/Interviews & 0 & 0.0 & 0 & 0.0 & 3 & 7.1 & 3 & 5.0 \\
\hline Theoretical & 4 & $\mathbf{5 7 . 1}$ & $\mathbf{1}$ & $\mathbf{9 . 1}$ & 4 & $\mathbf{9 . 5}$ & $\mathbf{9}$ & $\mathbf{1 5 . 0}$ \\
\hline & STATISTICAL TECHNIQUES & & & \\
\hline Descriptive & 2 & 3.3 & 1 & 9.1 & 1 & 2.4 & 4 & 6.7 \\
Univariate & 0 & 0.0 & 2 & 18.2 & 1 & 2.4 & 3 & 5.0 \\
Multivariate & 0 & 0.0 & 1 & 9.1 & 11 & 26.2 & 12 & 20.0 \\
SEM/PATH & 0 & 0.0 & 3 & 27.3 & 11 & 26.2 & 14 & 23.3 \\
N.A. & 5 & 8.3 & 4 & 36.4 & 18 & 42.9 & 27 & 45.0 \\
\hline TOTAL & 7 & $\mathbf{1 0 0 . 0}$ & $\mathbf{1 1}$ & $\mathbf{1 0 0 . 0}$ & $\mathbf{4 2}$ & $\mathbf{1 0 0 . 0}$ & $\mathbf{6 0}$ & $\mathbf{1 0 0 . 0}$ \\
\hline
\end{tabular}


Table 3: Areas, Topics and Technologies by period

\begin{tabular}{|c|c|c|c|c|c|c|c|c|c|}
\hline & \multirow[b]{2}{*}{ TOPICS } & \multicolumn{2}{|c|}{ Until 1999} & \multicolumn{2}{|c|}{$2000-2009$} & \multicolumn{2}{|c|}{ 2010-2019 } & \multicolumn{2}{|c|}{ Total } \\
\hline & & N. & $\%$ & N. & $\%$ & N. & $\%$ & N. & $\%$ \\
\hline & a. Technology \& Employees & 1 & 12.5 & 5 & 38.5 & 22 & 37.2 & 28 & 35.0 \\
\hline & TAM & 0 & 0.0 & 4 & 30.8 & 5 & 8.5 & 9 & 11.3 \\
\hline & Satisfaction & 1 & 12.5 & 0 & 0.0 & 3 & 5.1 & 4 & 5.0 \\
\hline & Engagement / Socialization & 0 & 0.0 & 0 & 0.0 & 4 & 6.8 & 4 & 5.0 \\
\hline & Cyberslacking & 0 & 0.0 & 0 & 0.0 & 3 & 5.1 & 3 & 3.8 \\
\hline & Turnover & 0 & 0.0 & 0 & 0.0 & 3 & 5.1 & 3 & 3.8 \\
\hline & eWom & 0 & 0.0 & 0 & 0.0 & 2 & 3.4 & 2 & 2.5 \\
\hline & Change Agent & 0 & 0.0 & 1 & 7.7 & 1 & 1.7 & 2 & 2.5 \\
\hline $\boldsymbol{A}$ & Digital DIY & 0 & 0.0 & 0 & 0.0 & 1 & 1.7 & 1 & 1.3 \\
\hline $\boldsymbol{R}$ & b. Technology \& HR Processes & 2 & 25.0 & 7 & 53.8 & 15 & 25.4 & 24 & 30.0 \\
\hline $\boldsymbol{E}$ & Training & 1 & 12.5 & 4 & 30.8 & 6 & 10.2 & 11 & 13.8 \\
\hline $\boldsymbol{A}$ & Recruitment / Selection & 1 & 12.5 & 1 & 7.7 & 7 & 11.9 & 9 & 11.3 \\
\hline$S$ & Knowledge Management & 0 & 0.0 & 0 & 0.0 & 2 & 3.4 & 2 & 2.5 \\
\hline & Diversity Management & 0 & 0.0 & 2 & 15.4 & 0 & 0.0 & 2 & 2.5 \\
\hline & c. Technology \& Results & 2 & 25.0 & 0 & 0.0 & 13 & 22.0 & 15 & 18.8 \\
\hline & Success Factors & 1 & 12.5 & 0 & 0.0 & 7 & 11.9 & 8 & 10.0 \\
\hline & Performance & 0 & 0.0 & 0 & 0.0 & 5 & 8.5 & 5 & 6.3 \\
\hline & Costs / Effic. & 1 & 12.5 & 0 & 0.0 & 1 & 1.7 & 2 & 2.5 \\
\hline & d. Technology \& Organizational Structures & 3 & 37.5 & 1 & 7.7 & 9 & 15.3 & 13 & 16.3 \\
\hline & Content/Knowledge & 2 & 25.0 & 1 & 7.7 & 6 & 10.2 & 9 & 11.3 \\
\hline & Technohumans & 0 & 0.0 & 0 & 0.0 & 3 & 5.1 & 3 & 3.8 \\
\hline & Post/Dpt. Destruction & 1 & 12.5 & 0 & 0.0 & 0 & 0.0 & 1 & 1.3 \\
\hline & TOTAL & 8 & 100.0 & 13 & 100.0 & 59 & 100.0 & 80 & 100.0 \\
\hline & TECHNOLOGIES & N. & $\%$ & N. & $\%$ & N. & $\%$ & N. & $\%$ \\
\hline & ICTs in general & 6 & 85.7 & 4 & 36.4 & 23 & 54.8 & 33 & 55.0 \\
\hline & Internet/Websites & 0 & 0.0 & 3 & 27.3 & 4 & 9.5 & 7 & 11.7 \\
\hline & Online Social Networks & 0 & 0.0 & 0 & 0.0 & 6 & 14.3 & 6 & 10.0 \\
\hline & Video & 1 & 14.3 & 0 & 0.0 & 2 & 4.8 & 3 & 5.0 \\
\hline & Robotics /AI & 0 & 0.0 & 0 & 0.0 & 2 & 4.8 & 2 & 3.3 \\
\hline & Front Office Systems & 0 & 0.0 & 1 & 9.1 & 1 & 2.4 & 2 & 3.3 \\
\hline & Others & 0 & 0.0 & 3 & 27.3 & 4 & 9.5 & 7 & 11.7 \\
\hline & TOTAL & 7 & 100.0 & 11 & 100.0 & 42 & 100.0 & 60 & 100.0 \\
\hline
\end{tabular}


Table 4: Papers published by Author and Country

\begin{tabular}{|c|c|c|c|}
\hline \multicolumn{4}{|c|}{ AUTHORS } \\
\hline Author & $\mathbf{N}$ & University & Country \\
\hline Law, Rob & 4 & Hong Kong Polytechnic Uni. & China \\
\hline Harris, Kimberley J. & 3 & $\begin{array}{l}\text { James Madison University, Florida State } \\
\text { University }\end{array}$ & USA \\
\hline Kim, Tae Goo & 3 & $\begin{array}{l}\text { Kyung Hee Univer., Cheju National } \\
\text { Univer. }\end{array}$ & South Korea \\
\hline Ladkin, Adele & 3 & $\begin{array}{l}\text { Bournemouth University, } \\
\text { Hong Kong Polytechnic Uni. }\end{array}$ & UK, China \\
\hline Qu, Hailin & 3 & Oklahoma State University & USA \\
\hline Buhalis, Dimitros & 2 & Bournemouth University & UK \\
\hline Bulchan-Guidumal, Jacques & 2 & Univer. Las Palmas de Gran Canaria & Spain \\
\hline Bonn, Mark A. & 2 & Florida State University & USA \\
\hline Davison, Robert M. & 2 & $\begin{array}{l}\text { Univer. Hong Kong, City Univer. of Hong } \\
\text { Kong }\end{array}$ & China \\
\hline Cho, Vincent & 2 & Hong Kong Polytechnic Uni. & China \\
\hline Janta, Hania & 2 & $\begin{array}{l}\text { University of Surrey, Bournemouth } \\
\text { Univer. }\end{array}$ & UK \\
\hline Kandampully, Jay & 2 & The Ohio State Univer. & USA \\
\hline Kim, Jungsun & 2 & Texas Tech Univer., Univer. of Nevada & USA \\
\hline Mejía, Cynthia & 2 & University of Central Florida & USA \\
\hline Melián-González, Santiago & 2 & Univer. Las Palmas de Gran Canaria & Spain \\
\hline Ou, Carol X.J. & 2 & Tilburg Univer. & Netherlands \\
\hline Sigala, Marianna & 2 & $\begin{array}{l}\text { Univer. of Aegean, Univer. of South } \\
\text { Australia }\end{array}$ & $\begin{array}{l}\text { Greece, } \\
\text { Australia }\end{array}$ \\
\hline Tavitiyaman, Pimtong & 2 & Hong Kong Polytechnic Univer. & China \\
\hline Torres Edwin N. & 2 & Univer. of Central Florida & USA \\
\hline Zhang, Hanqin Qiu & 2 & Hong Kong Polytechnic Uni. & China \\
\hline Zhang, Tingtin (Christina) & 2 & University of Central Florida & USA \\
\hline \multicolumn{4}{|c|}{ COUNTRIES } \\
\hline Country & $\mathbf{N}$ & Country & $\mathbf{N}$ \\
\hline USA & 43 & South Africa & 3 \\
\hline China & 33 & Taiwan & 2 \\
\hline UK & 17 & Denmark & 1 \\
\hline South Korea & 10 & France & 1 \\
\hline Spain & 8 & Greece & 1 \\
\hline Australia & 6 & Norway & 1 \\
\hline Malaysia & 6 & Zimbabwe & 1 \\
\hline Netherlands & 5 & Finland & 1 \\
\hline Austria & 3 & & \\
\hline
\end{tabular}




\section{APPENDIX}

Table 5: Topics, Research Methodologies and Key Findings

\begin{tabular}{|c|c|c|c|}
\hline Paper & $\begin{array}{l}\text { Research } \\
\text { Methodology }\end{array}$ & Topic & Key Findings \\
\hline $\begin{array}{l}\text { Ahmad and Scott } \\
\text { (2019) }\end{array}$ & $\begin{array}{l}\text { Case } \\
\text { study/Interviews }\end{array}$ & Costs / Effic. & $\begin{array}{l}\text { - Managers should know which technologies can save labor costs in the hotel industry. } \\
\text { - Hotels must assess the cost of technology versus the cost of not having it. } \\
\text { - Experts in robotics and ICTs in general must create technologies which serve to reduce labor costs at an } \\
\text { affordable price. }\end{array}$ \\
\hline Li et al. (2019) & Field study/survey & Turnover & $\begin{array}{l}\text { - Turnover intentions could be promoted through the use of Artificial Intelligence (AI) in hotels. } \\
\text { - If employees are supported by their organizations, turnover intentions will decrease. } \\
\text { - Organizational support could include such formats as the development of soft skills, e.g. communication, } \\
\text { time management, problem solving, interpersonal skills, leadership, and creative thinking. } \\
\text { Engaging in hobbies outside the working place is important for a good work-life balance. Therefore, } \\
\text { managers should encourage taking up hobbies to reduce turnover intentions. }\end{array}$ \\
\hline Shin et al. (2019) & $\begin{array}{l}\text { Case } \\
\text { Study/Interviews }\end{array}$ & $\begin{array}{l}\text { Training, } \\
\text { Recruitment / } \\
\text { Selection }\end{array}$ & $\begin{array}{l}\text { - Due to its ease of use, new front desk technology facilitates the processes to hire personnel for front desk } \\
\text { services. Hiring is consequently based on candidates' personality and service capacity (including } \\
\text { communication and personal skills), rather than on their technological skills. } \\
\text { - Most of hotel industry employees' training takes place on the job itself. If learning a new technology becomes } \\
\text { easier and faster, this will redound to its greater acceptance and use. }\end{array}$ \\
\hline $\begin{array}{l}\text { Stamolampros et al. } \\
\text { (2019) }\end{array}$ & Content Analysis & $\begin{array}{l}\text { eWOM, Satisfaction, } \\
\text { Turnover }\end{array}$ & $\begin{array}{l}\text { - Platforms such as Glassdoor where employees can rate their company offer valuable information to } \\
\text { understand the reasons for their satisfaction or dissatisfaction —or why they leave their company. } \\
\text { - The most satisfied employees typically highlight culture, leadership, and the career opportunities offered by } \\
\text { their companies as outstanding aspects. }\end{array}$ \\
\hline Sun et al. (2019) & Field study/survey & TAM & $\begin{array}{l}\text { - Cultural values such as collectivism and long-term orientation positively influence perceived ease of use as } \\
\text { well as perceived utility of technology by hotel employees. } \\
\text { - Hotel managers must consequently promote a collectivist culture to achieve greater acceptance of new } \\
\text { technologies. They also need to foster a long-term culture, for example, explaining the long-term benefits } \\
\text { that using technology can bring. Lastly, they must promote a more feminine culture as a way to decrease the } \\
\text { reluctance to adopt technology. }\end{array}$ \\
\hline $\begin{array}{l}\text { Yu and Ngan } \\
\text { (2019) }\end{array}$ & Experiment & Technohumans & $\begin{array}{l}\text { - The service provided by means of robots in the hospitality industry is evolving with humanoid robots; this } \\
\text { area has not yet reached a mature status, though. } \\
\text { - Customers expect to see a smile during hospitality service. Nevertheless, different types of clients perceive } \\
\text { the service differently depending on their gender or cultural background (amongst other factors). }\end{array}$ \\
\hline
\end{tabular}




\begin{tabular}{|c|c|c|c|}
\hline $\begin{array}{l}\text { Chingarande and } \\
\text { Saayman (2018) }\end{array}$ & Literature Review & Success Factors & $\begin{array}{l}\text { - Success factors influencing tourism growth include human resources and technological development, as well } \\
\text { as others such as tourist safety, commercial openness, environmental protection or financial development. } \\
\text { - Countries with higher levels of human resource and financial system development stand better opportunities } \\
\text { to develop the tourism sector to a greater extent. }\end{array}$ \\
\hline $\begin{array}{l}\text { Kandampully et al. } \\
\text { (2018) }\end{array}$ & Literature Review & Success Factors & $\begin{array}{l}\text { - Technology and human resources, amongst others, arise as critical factors to enhance customers' experience } \\
\text { in the hospitality industry. } \\
\text { - The combination of human resource management, marketing, and operational elements can largely contribute } \\
\text { to provide an individualized memorable experience. }\end{array}$ \\
\hline $\begin{array}{l}\text { Kim and Gatling } \\
(2018)\end{array}$ & Field study/survey & $\begin{array}{l}\text { Engagement / } \\
\text { Socialization, TAM }\end{array}$ & $\begin{array}{l}\text { - Employees adopt VEEPs (Virtual Employee Engagement Platforms) mainly because of the useful functions } \\
\text { that they offer. VEEPs' ease of use is not as important as system usefulness. } \\
\text { - Some of the functions that a VEEP System can have are storing and giving access to HR-related documents, } \\
\text { serving as a repository to share ideas, to recognize achievements, to notify schedule changes and events, and } \\
\text { to provide information about the arrival of VIPs, about work posts available... } \\
\text { - VEEPs can help improve employees' engagement with the company. }\end{array}$ \\
\hline $\begin{array}{l}\text { Mejía and Torres } \\
(2018)\end{array}$ & $\begin{array}{l}\text { Case } \\
\text { Study/Interviews }\end{array}$ & $\begin{array}{l}\text { Recruitment / } \\
\text { Selection }\end{array}$ & $\begin{array}{l}\text { - Hospitality firms can consider AVI (asynchronous video interviewing) as an attractive recruitment tool. Such } \\
\text { interviews prove especially suitable during the initial stages of recruitment processes for management posts. } \\
\text { - } \quad \text { Better candidates could thus pass directly to the face-to-face interview. }\end{array}$ \\
\hline $\begin{array}{l}\text { Pikkemaat et al. } \\
(2018)\end{array}$ & $\begin{array}{l}\text { Case } \\
\text { Study/Interviews }\end{array}$ & Success Factors & $\begin{array}{l}\text { - Destination Management organizations can undertake several actions to foster innovation, some of them } \\
\text { related to Human resources and others to Technologies. } \\
\text { - Regarding employee development, they (DMOs) can develop corporate brand building initiatives as well as } \\
\text { joint employee training programs. } \\
\text { - As for ICTs, they should develop ICT knowledge and information transfer platforms for tourism. }\end{array}$ \\
\hline Sigala (2018) & Theoretical & $\begin{array}{l}\text { Content/Knowledge, } \\
\text { Technohumans }\end{array}$ & $\begin{array}{l}\text { - Both anthropomorphic robots and smart automated online assistants, alongside artificial intelligence, can } \\
\text { help and develop service delivery in positions such as museum guides, hotel receptions, restaurant waiters, } \\
\text { or airport welcome staff. These near-human technologies are going to transform workplace productivity, } \\
\text { even substituting employees. } \\
\text { - Nonetheless, knowledge and skills associated with innovation, pattern recognition, multisensory } \\
\text { communication, and the development of creative solutions to previously unimagined problems will be the } \\
\text { most demanded knowledge for future employees. }\end{array}$ \\
\hline $\begin{array}{l}\text { Yadegaridehkordi } \\
\text { et al. (2018) }\end{array}$ & Field study/survey & Success Factors & $\begin{array}{l}\text { - Critical success factors influencing hotel tourism industry development are of a human, technological, } \\
\text { environmental, and organizational nature. } \\
\text { - Human factors include customer satisfaction, employee training and empowerment, together with } \\
\text { management support. Employees must be trained to obtain customers' satisfaction. Managers need to } \\
\text { exercise efficient leadership, which helps reduce staff turnover and gain loyalty. }\end{array}$ \\
\hline
\end{tabular}




\begin{tabular}{|c|c|c|c|}
\hline & & & $\begin{array}{l}\text { - Amongst technological factors stands out IT use. The utilization of the Internet and communication } \\
\text { technologies has become very popular as a means to gain a competitive advantage through connections with } \\
\text { potential hotel customers and providers. }\end{array}$ \\
\hline Yuan et al. (2018) & Field study/survey & $\begin{array}{l}\text { Performance, } \\
\text { Satisfaction, } \\
\text { Turnover }\end{array}$ & $\begin{array}{l}\text { - Coercive acquaintance advertising is causing workers to have negative results in their work, e.g. lower } \\
\text { performance, less satisfaction, and turnover intentions. This is due to the dilemma that employees must face: } \\
\text { acting as friends or as workers. }\end{array}$ \\
\hline $\begin{array}{l}\text { Davison and } \mathrm{Ou} \\
\text { (2017) }\end{array}$ & $\begin{array}{l}\text { Case } \\
\text { Study/Interviews }\end{array}$ & $\begin{array}{l}\text { Digital DIY, } \\
\text { Cyberslacking }\end{array}$ & $\begin{array}{l}\text { - Many employees see digital DIY as a way not only to overcome the limitations of strongly centralized IT } \\
\text { policies - helped by their higher digital literacy - but also to successfully cope with an ever-changing } \\
\text { environment. } \\
\text { - Digitally savvy employees create a new technological spirit by leading innovations, rejecting control of } \\
\text { technology solely by the IT department. }\end{array}$ \\
\hline $\begin{array}{l}\text { Melián-González } \\
\text { and Bulchand- } \\
\text { Gidumal (2017a) }\end{array}$ & Experiment & eWOM & $\begin{array}{l}\text { - Employer review websites are spaces where employees post their opinions and comments about their } \\
\text { company that may have significant consequences for the latter. } \\
\text { - The negative or positive opinions of employees about their companies can influence their customers' } \\
\text { opinions and, accordingly, their reservation intentions. }\end{array}$ \\
\hline $\begin{array}{l}\text { Melián-González } \\
\text { and Bulchand- } \\
\text { Gidumal (2017b) }\end{array}$ & $\begin{array}{l}\text { Case } \\
\text { Study/Interviews }\end{array}$ & Performance & $\begin{array}{l}\text { - Employees must have the ability to surprise customers by offering the kind of attention that no machine can } \\
\text { provide. } \\
\text { - } \\
\text { - A differentiation strategy at a luxury hotel will require excellent employee behaviors, whereas a cost-based } \\
\text { strategy at a three-star hotel could ignore some employee attentions. }\end{array}$ \\
\hline Rahimi (2017) & Field study/survey & Success Factors & $\begin{array}{l}\text { - Hotels implementing CRM successfully will achieve customers' loyalty and long-term profitability. } \\
\text { - A consistent culture formed by shared values amongst employees will lead to consistent decision-making } \\
\text { and favor a successful CRM. }\end{array}$ \\
\hline $\begin{array}{l}\text { Torres and Mejía } \\
(2017)\end{array}$ & Theoretical & $\begin{array}{l}\text { Recruitment / } \\
\text { Selection }\end{array}$ & $\begin{array}{l}\text { - Hospitality companies use a variety of staff recruitment tools, including technology-based ones. The } \\
\text { implementation of Asynchronous Video Interviews (AVIs) can serve various purposes, e.g. reducing costs, } \\
\text { increasing efficiency, and even reaching a larger number of interviewees. } \\
\text { AVIs, which should combine with other tools as a recruitment method, may not prove suitable for all types } \\
\text { of positions. }\end{array}$ \\
\hline $\begin{array}{l}\text { Kandampully et al. } \\
\text { (2016) }\end{array}$ & Theoretical & Change Agent & $\begin{array}{l}\text { - Hospitality industry managers must adopt strategies to stay ahead of innovation by engaging both employees } \\
\text { and customers so that they can use technology in order to co-create. } \\
\text { - Due to the critical value of personnel in hospitality companies, fostering a unique climate and culture for } \\
\text { employees that will be reflected in customer experiences becomes a must. }\end{array}$ \\
\hline $\begin{array}{l}\text { Ladkin and Buhalis } \\
\text { (2016) }\end{array}$ & Theoretical & $\begin{array}{l}\text { Recruitment / } \\
\text { Selection }\end{array}$ & $\begin{array}{l}\text { - } \quad \text { Online social media could be used for recruitment purposes. } \\
\text { - } \quad \text { Social, legal, and operational changes are taking place in the recruitment process. } \\
\text { - } \quad \text { Human resource managers should be dealing with these emerging practices in the hospitality sector. }\end{array}$ \\
\hline
\end{tabular}




\begin{tabular}{|c|c|c|c|}
\hline Ou et al. (2016) & Field study/survey & $\begin{array}{l}\text { Knowledge } \\
\text { Management }\end{array}$ & $\begin{array}{l}\text { - Interactive systems are used for knowledge sharing purposes in hotels. } \\
\text { - Good guanxi networks should be developed and maintained in tourism organizations, as they can improve } \\
\text { employees' performance. } \\
\text { - Technology and guanxi could combine; they are by no means mutually exclusive. }\end{array}$ \\
\hline $\begin{array}{l}\text { Rosa and Hastings } \\
(2016)\end{array}$ & $\begin{array}{l}\text { Case } \\
\text { Study/Interviews }\end{array}$ & Cyberslacking & $\begin{array}{l}\text { - Millennial employees violate the rules regarding mobile use in the hotel industry. } \\
\text { - Organizations must provide an open dialogue to achieve employees' engagement. If millennial employees } \\
\text { are committed to the company and respect managers, they will not violate any business rules. }\end{array}$ \\
\hline Solnet et al. (2016) & $\begin{array}{l}\text { Content Analysis/ } \\
\text { interviews }\end{array}$ & Content/Knowledge & $\begin{array}{l}\text { - The substitution of jobs by technology with the aim of automating the most routine and least qualified tasks } \\
\text { arises as one of the future hotel trends. } \\
\text { - Although there will presumably be key positions which cannot be replaced, other peripheral jobs may be } \\
\text { demanded just in time. }\end{array}$ \\
\hline $\begin{array}{l}\text { Ravichandran et al. } \\
\text { (2015) }\end{array}$ & $\begin{array}{l}\text { Case } \\
\text { Study/Interviews }\end{array}$ & Training & $\begin{array}{l}\text { - Contrary to usual belief, older employees are not against training; in fact, they consider training essential to } \\
\text { their performance. } \\
\text { - Older employees recognize the benefits of technology when it comes to training but are frustrated by the } \\
\text { shortage of time spent learning new technologies. }\end{array}$ \\
\hline $\begin{array}{l}\text { Sigala and Chalkiti } \\
(2015)\end{array}$ & Field study/survey & $\begin{array}{l}\text { Knowledge } \\
\text { Management }\end{array}$ & $\begin{array}{l}\text { - Online social media can foster both employee creativity and creative processes by helping employees share } \\
\text { their knowledge. } \\
\text { Online social networks can enrich knowledge management, obtaining adequate mixes of employees based } \\
\text { on their different leadership capacities, personality or educational background, and forming teams that can } \\
\text { provide creative solutions to business problems, such as innovation, customer complaint management and } \\
\text { new service development, to quote but a few. }\end{array}$ \\
\hline Wu et al. (2015) & Experiment & Technohumans & $\begin{array}{l}\text { - Wearable Technology can contribute either to the success of a service or to its failure; hotel check-in activities } \\
\text { could exemplify this. } \\
\text { - Clients react differently depending on gender. Customers expect male employees to be more skilled in the } \\
\text { use of technology and consequently assess their service more severely when failure occurs. }\end{array}$ \\
\hline $\begin{array}{l}\text { Inversini and } \\
\text { Masiero (2014) }\end{array}$ & Field study/survey & Content/Knowledge & $\begin{array}{l}\text { - Hotel companies are now present on online social networks and OTAs (Online Travel Agents) for the purpose } \\
\text { of increasing their visibility and sales. } \\
\text { - } \quad \text { This requires trained personnel with a wide range of different skills and training needs. }\end{array}$ \\
\hline $\begin{array}{l}\text { Cohen and Olsen } \\
(2013)\end{array}$ & Field study/survey & $\begin{array}{l}\text { Performance, } \\
\text { Content/Knowledge }\end{array}$ & $\begin{array}{l}\text { - The best performing hospitality establishments are those with more satisfied employees and better IT } \\
\text { resources. } \\
\text { - HR management skills associated with the ability to reward, incentivize, and train employees are necessary } \\
\text { to support the development of employees' knowledge management skills. IT must simultaneously interact } \\
\text { with organizational processes to improve organizational performance. }\end{array}$ \\
\hline
\end{tabular}




\begin{tabular}{|c|c|c|c|}
\hline $\begin{array}{l}\text { Janta and Ladkin } \\
(2013)\end{array}$ & Content Analysis & $\begin{array}{l}\text { Engagement/Socializ } \\
\text { ation, Recruitment / } \\
\text { Selection }\end{array}$ & $\begin{array}{l}\text { - Future migrants enjoy the support that their compatriots already installed in the destination country offer } \\
\text { them through online social networks. } \\
\text { - } \quad \text { Already-installed migrants will therefore become an important recruitment agent. }\end{array}$ \\
\hline $\begin{array}{l}\text { Au and Cheng } \\
(2012)\end{array}$ & Field study/survey & Satisfaction & $\begin{array}{l}\text { - If the perceived effort required to use a technology outweighs the needs met by that technology, the end user } \\
\text { (the employee) will be happy to adopt such technology. } \\
\text { Before trying to obtain benefits through the utilization of any technology, it must be ensured that employees } \\
\text { are both able and ready to use it. } \\
\text { Employees stand out as one of the most valuable resources owned by an airline. Therefore, ensuring their } \\
\text { satisfaction with airline ISs becomes essential: if an employee is frustrated and unhappy, that will negatively } \\
\text { impact on their customers' experience. }\end{array}$ \\
\hline Janta et al. (2012) & $\begin{array}{l}\text { Content } \\
\text { Analysis/intervie } \\
\text { ws }\end{array}$ & $\begin{array}{l}\text { Training, } \\
\text { Engagement/Socializ } \\
\text { ation }\end{array}$ & $\begin{array}{l}\text { - Online forums turn into virtual learning spaces that can prove useful to learn a language - as well as to } \\
\text { exchange practical information- where migrants offer their compatriots support. } \\
\text { - } \quad \text { Online social networks thus become a virtual space for the socialization of new migrant employees. }\end{array}$ \\
\hline Madera (2012) & Experiment & $\begin{array}{l}\text { Recruitment / } \\
\text { Selection }\end{array}$ & $\begin{array}{l}\text { - Organizations use online social networking sites for selection processes, though applicants could perceive } \\
\text { these practices as unfair and even as a privacy violation. } \\
\text { Applicant selections by means of online social networks could involve reliability and validity problems; } \\
\text { hence why organizations should cautiously approach selection decisions based on information obtained from } \\
\text { online social media. }\end{array}$ \\
\hline $\begin{array}{l}\text { Tavitiyaman et al. } \\
(2012)\end{array}$ & Field study/survey & $\begin{array}{l}\text { Performance, Success } \\
\text { Factors }\end{array}$ & $\begin{array}{l}\text { - A Competitive Human Resource strategy directly influences the behavioral performance of hotels. A } \\
\text { competitive IT strategy strongly impacts on their financial performance. Organizational structure moderates } \\
\text { both effects. } \\
\text { - When an environment is uncertain, the organizational structure should be carefully selected. An organic } \\
\text { structure allows more flexibility in the workplace; however, this can mean a loss in terms of employee control } \\
\text { and productivity. }\end{array}$ \\
\hline $\begin{array}{l}\text { Cheng and Cho } \\
\text { (2011) }\end{array}$ & Field study/survey & TAM & $\begin{array}{l}\text { - The use of technologies is more strongly affected by personal attitudes than by subjective norms. } \\
\text { - The characteristics that largely affect employees' attitudes towards the adoption of new technologies are: } \\
\text { perceived utility; perceived ease of use; observability (possibility of seeing the results of a specific } \\
\text { innovation); and trialability (possibility of testing). }\end{array}$ \\
\hline $\begin{array}{l}\text { Chu and Chu } \\
(2011)\end{array}$ & Field study/survey & $\begin{array}{l}\text { Engagement/Socializ } \\
\text { ation }\end{array}$ & $\begin{array}{l}\text { - Intranets can prove helpful as a socialization tool for newcomers in a hotel. } \\
\text { - Pre-training for the hotel intranet can increase the use of this technology and shorten the socialization period } \\
\text { of newcomers. } \\
\text { - Information regarding company policies and contact information should be amongst those provided by an } \\
\text { Intranet. }\end{array}$ \\
\hline $\begin{array}{l}\text { Davidson et al. } \\
\text { (2011) }\end{array}$ & Literature Review & $\begin{array}{l}\text { Content/Knowledge, } \\
\text { Training }\end{array}$ & $\begin{array}{l}\text { - Many of the challenges in the hospitality industry have revolved around the development of employees' } \\
\text { training and skills, since that is the way to instill new standards and improve customer satisfaction levels. }\end{array}$ \\
\hline
\end{tabular}




\begin{tabular}{|c|c|c|c|}
\hline & & & $\begin{array}{l}\text { - Technology has had a huge impact on the hospitality industry. In the HRM area, technology has been } \\
\text { introduced in every administrative system and is seemingly able to perform many comprehensive HRM } \\
\text { functions in a highly satisfactory manner. }\end{array}$ \\
\hline $\begin{array}{l}\text { Gibson and Swift } \\
\text { (2011) }\end{array}$ & $\begin{array}{l}\text { Content } \\
\text { Analysis/intervie } \\
\text { ws }\end{array}$ & $\begin{array}{l}\text { Recruitment / } \\
\text { Selection }\end{array}$ & $\begin{array}{l}\text { - The Internet plays a key role in the success of a recruitment strategy, the advantages that it offers - e.g. costs } \\
\text { and efficiency- outweighing its potential derived problems. } \\
\text { - A critical need exists to develop e-recruitment in cruise companies. } \\
\text { - Online recruitment enables companies to showcase their product - what they do- and to attract the most } \\
\text { desirable job applicants. }\end{array}$ \\
\hline Gröschl (2011) & Content Analysis & Diversity Manag. & $\begin{array}{l}\text { - Hotel companies need to communicate and display their Diversity Management policies more widely through } \\
\text { corporate websites. } \\
\text { - This communication will enhance the company's recruitment and selection efforts, attracting talents with } \\
\text { different cultural or educational backgrounds, while also publicizing its CSR policies. }\end{array}$ \\
\hline Ip et al. (2011) & Literature Review & $\begin{array}{l}\text { Training, } \\
\text { Cyberslacking, TAM, } \\
\text { Content/Knowledge }\end{array}$ & $\begin{array}{l}\text { - Hotel employees must remain up to date in training to improve their operational efficiency alongside service } \\
\text { quality. Using the Internet is one way to offer training to employees so that they can stay competitive. } \\
\text { Although the Internet brings many advantages to jobs, it may be a source of distraction for employees too. } \\
\text { Cyberslacking is one of the problems that arise when employees use the Internet during their working hours } \\
\text { for non-labor-related purposes. } \\
\text { - A direct correlation exists between perceived ease of use, perceived utility, and the adoption of POS (Point } \\
\text { of Sale) systems by employees. } \\
\text { - Hospitality companies need to maintain adequate relationships with their customers using ICTs and } \\
\text { integrating such technologies into their strategies. }\end{array}$ \\
\hline Kim et al. (2011) & Field study/survey & Training & $\begin{array}{l}\text { - Hotel employees, including those not being in management areas, value soft skills (i.e. responsibility, } \\
\text { sociability, self-management, problem solving, self-esteem, decision making, integrity and honesty...) to } \\
\text { perform their job. } \\
\text { - E-learning programs for hotel employees should help develop soft skills. }\end{array}$ \\
\hline $\begin{array}{l}\text { Tavitiyaman et al. } \\
\text { (2011) }\end{array}$ & Field study/survey & $\begin{array}{l}\text { Performance, Success } \\
\text { Factors }\end{array}$ & $\begin{array}{l}\text { - Hotels whose clients have little bargaining power and face a low threat from new competitors follow strong } \\
\text { competitive strategies in Human Resources and IT. } \\
\text { - On the contrary, those hotels which are at an advantage over their competitors do not show much } \\
\text { competitiveness in terms of their IT or Human Resource strategies or concerning their brand image. } \\
\text { Competitive Human Resource and IT strategies favor a higher performance of hotels. Brand image strategy } \\
\text { has no influence, though. This may happen because brand image development overlaps with IT and Human } \\
\text { Resource strategies. }\end{array}$ \\
\hline Kim et al. (2010) & Field study/survey & TAM & $\begin{array}{l}\text { - The attitude towards the use of HISs (Hotel Information Systems) depends on their usefulness to a greater } \\
\text { extent than on their ease of use. }\end{array}$ \\
\hline
\end{tabular}




\begin{tabular}{|c|c|c|c|}
\hline & & & $\begin{array}{l}\text { - Since the fit between an HIS and the tasks to be performed is greater, employees perceive the system as easier } \\
\text { to use and more useful. } \\
\text { - } \quad \text { The shorter the time it takes to learn how to use an HIS, the greater the motivation to accept it. }\end{array}$ \\
\hline $\begin{array}{l}\text { Benders et al. } \\
(2009) \text {. }\end{array}$ & $\begin{array}{l}\text { Case } \\
\text { Study/Interviews }\end{array}$ & Content/Knowledge & $\begin{array}{l}\text { - Employees must play a key role in the implementation of ERP systems, insofar as these systems can influence } \\
\text { the content of their jobs. } \\
\text { - Decentralization in decision-making becomes safer by allowing a greater degree of control. Therefore, the } \\
\text { system must be configured so that jobs can become more meaningful. }\end{array}$ \\
\hline Huh et al. (2009) & Field study/survey & TAM & $\begin{array}{l}\text { - Perceived usefulness is a predictor of HIS acceptance. Therefore, Hotel Information Systems should offer } \\
\text { varied information about jobs. This could help an HIS to be perceived as more useful. } \\
\text { - An HIS must be easy to use, so that its acceptance by employees will grow. Another important characteristic } \\
\text { that determines the attitude towards this technology is its compatibility. } \\
\text { - It would be appropriate for HISs to offer the possibility to exchange information between their different } \\
\text { subsystems, e.g. reception, back office, or point of sale systems. }\end{array}$ \\
\hline $\begin{array}{l}\text { Lema and Agrusa } \\
\text { (2009) }\end{array}$ & Field study/survey & Training & $\begin{array}{l}\text { - Those employees who have greater experience with WWW-based applications will be more motivated to } \\
\text { engage in self-directed learning. } \\
\text { - Self-directed learning will in turn provide employees with more opportunities to practice making decisions } \\
\text { and to develop critical thinking skills. }\end{array}$ \\
\hline Nisbet (2009) & $\begin{array}{l}\text { Case } \\
\text { Study/Interviews }\end{array}$ & Change Agent & $\begin{array}{l}\text { - Employees could act as change agents in the promotion of new technologies amongst clients (in casinos). } \\
\text { - Employees could assume this role in different ways: emphasizing the safety (security and reliability) of } \\
\text { technology; monitoring customers during the first week after registration; focusing on customers with the } \\
\text { potential to achieve greater satisfaction through the adoption of technologies; communicating their } \\
\text { satisfaction through word-of-mouth; acknowledging that technology is not the best solution for every } \\
\text { customer; making it clear to customers that its adoption is not mandatory, but voluntary; as well as valuing } \\
\text { and taking advantage of feedback. }\end{array}$ \\
\hline Kim et al. (2008) & Field study/survey & TAM & $\begin{array}{l}\text { - HFOSs (Hotel Front Office Systems) must offer fast and secure transactions so that employees can use their } \\
\text { time serving their customers. } \\
\text { - Frontline employees should be aware of the benefits brought by using these systems, which lead to better on- } \\
\text { the-job results. }\end{array}$ \\
\hline Kimes (2008) & Theoretical & TAM & $\begin{array}{l}\text { - The profitability of restaurants could improve thanks to technology. } \\
\text { - Technology can favor customers' perception of control and therefore improve their level of satisfaction, } \\
\text { increasing the chances of a repeat visit. } \\
\text { - If users see that a system is more convenient for them and that it helps them in their work, they will perceive } \\
\text { it as a more user-friendly one. }\end{array}$ \\
\hline Lam et al. (2007) & Field study/survey & TAM & - $\quad$ Employees are more motivated to use a technology when they need less time to master it. \\
\hline
\end{tabular}




\begin{tabular}{|c|c|c|c|}
\hline & & & $\begin{array}{l}\text { - Hotel managers play a decisive role when it comes to persuading employees to embrace new technologies. } \\
\text { Managers must ensure that employees have continuous feedback and support so that they will be encouraged } \\
\text { to use technology in a short period of time. } \\
\text { - Employees should be aware of all the improvements that using technology can bring to hotels in sales areas, } \\
\text { customer satisfaction, service quality and productivity improvements, and even in the reduction of labor } \\
\text { accidents. }\end{array}$ \\
\hline Furunes (2005) & Field study/survey & Training & $\begin{array}{l}\text { - Effectiveness paradoxically seems not to be the criterion that most influences the training methods adopted } \\
\text { by organizations. } \\
\text { - Smaller organizations continue to use traditional training methods, such as individual training or lecturers. } \\
\text { Larger ones, however, complete these methods with others, e.g. case studies, role-playing games, self- } \\
\text { assessment, videos, computer-assisted training, and multimedia presentations. }\end{array}$ \\
\hline $\begin{array}{l}\text { Abellá Garcés et al. } \\
\text { (2004) }\end{array}$ & Field study/survey & $\begin{array}{l}\text { Training, } \\
\text { Recruitment / } \\
\text { Selection }\end{array}$ & $\begin{array}{l}\text { - The most advanced technologies and databases reduce the need for human intervention in many transactions. } \\
\text { - The more internal training, the greater the use of e-commerce. Personnel who can understand and exploit } \\
\text { technology are needed to effectively harness e-commerce. } \\
\text { - Managerial attitude can become a barrier to e-commerce utilization by employees. }\end{array}$ \\
\hline $\begin{array}{l}\text { Harris and Boon } \\
(2000)\end{array}$ & Field study/survey & $\begin{array}{l}\text { Diversity Manag., } \\
\text { Training }\end{array}$ & $\begin{array}{l}\text { - Foodservice training programs need to improve both their training programs and the way to deliver them. } \\
\text { - More diverse training techniques and tools will serve to meet the challenges posed by training increasingly } \\
\text { multicultural and multilingual employees. }\end{array}$ \\
\hline Hjalager (1999) & Theoretical & Content/Knowledge & $\begin{array}{l}\text { - A shift in restaurants' division of labor is causing some of the operational work to move toward suppliers. } \\
\text { - Technology ideally provides opportunities to empower jobs. Technology productivity gains may be used to } \\
\text { train staff. This development will allow for an increased focus on interpersonal and communication skills } \\
\text { and capabilities. } \\
\text { - In haute cuisine restaurants where customers do not complain about high prices, backstage technology } \\
\text { investments can turn into an image enhancement for their workers - seen as more expert and elegant. }\end{array}$ \\
\hline Woods (1999) & Theoretical & Post/Dpt. destruction & $\begin{array}{l}\text { - Although the Human Resource department of the future may become much more important, it is likely to be } \\
\text { replaced by outsourcing and technology as well. } \\
\text { - Problems assigned to the Human Resource department in the hospitality sector include: the HR department } \\
\text { has no vision; its mission is diffuse; it lacks updated information; it does not act timely. For Human Resources } \\
\text { departments not to disappear, they must accomplish a goal, that of exercising leadership and building } \\
\text { organizations where people matter. }\end{array}$ \\
\hline Harris (1995) & Field study/survey & $\begin{array}{l}\text { Recruitment / } \\
\text { Selection }\end{array}$ & $\begin{array}{l}\text { - The most traditional training formats in the hospitality sector are supported by senior management, despite } \\
\text { the reluctance of the staff who receive this sort of training. } \\
\text { - Hospitality companies must analyze new training methods, evaluating both the costs and the short- and long- } \\
\text { term benefits that computer technologies bring to training. }\end{array}$ \\
\hline
\end{tabular}




\begin{tabular}{|c|c|c|c|}
\hline Berger et al. (1993) & Field study/survey & Success Factors & $\begin{array}{l}\text { - The HRM identity crisis of the } 1990 \text { s will have ended in the } 21 \text { st century, HRM positioning itself as a } \\
\text { strategic partner within hospitality industry firms. } \\
\text { HRM will play a relevant role in several aspects: the balance between employees' personal, family and work } \\
\text { life; the adoption of new technologies; employees' training, development, and promotion; and power } \\
\text { paradigms inside the organization. }\end{array}$ \\
\hline $\begin{array}{l}\text { Buchanan and } \\
\text { McCalman (1988) }\end{array}$ & $\begin{array}{l}\text { Case } \\
\text { Study/Interviews }\end{array}$ & Content/Knowledge & $\begin{array}{l}\text { - Computer systems can play an essential role by helping middle managers with their decision-making, rather } \\
\text { than replacing them. }\end{array}$ \\
\hline Harris (1988) & Theoretical & Training & $\begin{array}{l}\text { - Interactive video technology is entering the information age as we move from being bombarded with data to } \\
\text { knowing how to handle and apply this technology. } \\
\text { - } \quad \text { Training students and workers with technology has a reasonable cost, since it is a highly motivating tool. }\end{array}$ \\
\hline Kasavana (1982) & Theoretical & $\begin{array}{l}\text { Satisfaction, Costs / } \\
\text { Effic. }\end{array}$ & $\begin{array}{l}\text { - The introduction of computerized information systems means that employees will have more time to take } \\
\text { care of customers and to meet their needs. } \\
\text { - These systems improve customer service, reduce disputes related to billing, boost employees' morale, and } \\
\text { save costs. }\end{array}$ \\
\hline
\end{tabular}


